\title{
Investing Cash Transfers to Raise Long-Term Living Standards
}

\author{
Paul Gertler \\ Sebastian Martinez \\ Marta Rubio-Codina
}

In this paper we test whether poor households use cash transfers to invest in income generating activities that they otherwise would not have been able to do. Using data from a controlled randomized experiment, we find that transfers from the OPORTUNIDADES program to households in rural Mexico resulted in increased investment in micro-enterprise and agricultural activities. For each peso transferred, beneficiary households used 88 cents to purchase consumption goods and services, and invested the rest. The investments improved the household's ability to generate income with an estimated rate of return of $17.55 \%$, suggesting that these households were both liquidity and credit constrained. By investing transfers to raise income, beneficiary households were able to increase their consumption by $34 \%$ after five and a half years in the program. These results suggest that cash transfers to the poor may raise long-term living standards, which are maintained after program benefits end.

JEL Codes: I38, D12, D13, O12

Keywords: conditional cash transfer programs, randomized experiment, long run living standards, agricultural investments, micro-enterprise activity, liquidity and credit constraints.

World Bank Policy Research Working Paper 3994, August 2006

The Impact Evaluation Series has been established in recognition of the importance of impact evaluation studies for World Bank operations and for development in general. The series serves as a vehicle for the dissemination of findings of those studies. Papers in this series are part of the Bank's Policy Research Working Paper Series. The papers carry the names of the authors and should be cited accordingly. The findings, interpretations, and conclusions expressed in this paper are entirely those of the authors. They do not necessarily represent the views of the International Bank for Reconstruction and Development/World Bank and its affiliated organizations, or those of the Executive Directors of the World Bank or the governments they represent.

Acknowledgements: We have benefited from comments by Alain de Janvry, Pierre Dubois, Edward Miguel, Elizabeth Sadoulet, John Skinner, Doug Staiger, Chris Udry and seminar participants at UC Berkeley, The World Bank, University of Toulouse, Stanford University, Columbia University, Yale University, the Mexican National Institute of Public Health and the NEUDC meetings at Brown University. We thank the OPORTUNIDADES program for its support, and in particular Rogelio Gomez-Hermosillo, Concepcion Steta and Iliana Yaschine. For the qualitative field work we gratefully acknowledge support from UCMEXUS and assistance from Sarit Beith-Halachmi, Giovanna Limongi, Ryo Shiba, and Jennifer Sturdy.

Affiliation and Contact Information: Paul Gertler, Haas School of Business, University of California, Berkeley and World Bank; gertler@,haas.berkeley.edu. Sebastian Martinez, World Bank, smartinez@worldbank.org, Marta Rubio-Codina, University of Toulouse (GREMAQ, INRA), marta.rubio@univ-tlse1.fr. 


\section{Introduction}

Five years ago when my oldest daughter was in school and we received money from PROGRESA, we saved 600 pesos to buy wood and the other materials for building a chicken coup, and with what was left we bought a few chickens. Since then, we have raised many chickens which we sometimes sell, and we collect 10 to 15 eggs per week that we eat ourselves.

OPORTUNIDADES (PROGRESA) beneficiary in rural Mexico (August 2004) ${ }^{l}$

Cash transfer programs are important policy tools for fighting poverty in both developed and developing countries. A major concern in developed countries has been the extent to which beneficiary populations become dependent on government assistance for maintaining current consumption levels ${ }^{2}$. In contrast, we argue that beneficiary families in developing countries may invest part of their cash transfer in productive enterprises that boost their income generating ability and consequently raise living standards permanently. We test this hypothesis using a controlled randomized experiment to identify the extent to which beneficiary households from Mexico's OPORTUNIDADES $^{3}$ program invested cash transfers in income generating activities, and the extent to which those investments increased long-term household consumption.

In developing countries there are two primary pathways by which transfers correct market failures that limit investment in productive activities. First, transfers alleviate liquidity and credit constraints that contribute to poverty traps, whereby poor households are able to afford the startup costs associated with entrepreneurial activities ${ }^{4}$. The households studied here, with under US \$1 per day in per capita consumption, are likely to be liquidity constrained, and therefore unlikely to be able to afford the "low" levels of capital investment needed to start micro-entrepreneurial activities $^{5}$. Second, if transfers are perceived as a secure source of income, risk adverse households will be more willing to increase ownership of risky assets, even in the presence of risk. In these

\footnotetext{
${ }^{1}$ From a qualitative survey of agricultural production and micro-enterprise activity in rural Mexico, conducted by the authors. Interview from August 3, 2004.

2 See Moffit (1992) for a review of the US case.

${ }^{3}$ Skoufias (2005) provides a description of the program.

${ }^{4}$ Models along these lines are developed by authors including Banerjee and Newman (1993), Aghion and Bolton (1997), Lindh and Ohlsson (1998), Lloyd-Ellis and Bernhardt (2000), and Banerjee (2004).

${ }^{5}$ McKenzie and Woodruff (2006) report that it takes \$100 USD to start a micro-enterprise in Mexico.
} 
ways, monetary assistance from OPORTUNIDADES provides a secure income stream that may help alleviate liquidity constraints and grant access to capital, leading to increased investment ${ }^{6}$.

This study uses the randomized experiment from the rural evaluation of the OPORTUNIDADES conditional cash transfer program to estimate the impact of an exogenous increase in unearned income on investment and long-term living standards. We find that beneficiaries invest in production and draft animals, and that previously landless beneficiary households obtain land for agricultural production. Furthermore, there are significant increases in the number of households that operate micro-enterprises. Our estimates indicate that for each peso transferred, beneficiary households consume 88 cents directly, and invest the rest. The aggregate effect of the investments yields a 1.8 cent increase in consumption for each peso of transfers received. These estimates indicate an estimated rate of return on investment of between $15.52 \%$ and 17.55\%. Through investments in productive activities, beneficiary households increased their consumption by $34 \%$ after five and a half years in the program. Because investments are made in productive assets and income-generating activities, the gains in living standards will likely be maintained even after program benefits end.

Our study contributes to the relatively small literature that examines the potential impact of cash transfer programs on long-term living standards. Ravallion and Chen (2005) show that the lion's share of temporary cash transfers given by an anti-poverty program in China were saved. Sadoulet, de Janvry and Davis (2001) argue that payments from the Mexican agricultural support program PROCAMPO are invested in farm production, and estimate an income multiplier in the range of 1.5 to 2.6. While not related directly to cash transfer programs, studies by Yang (2005) and Woodruff and Zenteno (2001), show that remittances are used as capital to invest in microenterprises in the Philippines and Mexico, respectively.

The paper is organized as follows. Sections 1 and 2 describe the OPORTUNIDADES human development program and review the program's experimental design and data. In section 3,

\footnotetext{
${ }^{6}$ Investment will also depend on expectations about the transfer's temporal horizon and life-cycle considerations (Modigliani and Brumberg 1954; Friedman 1957 and Hall 1978).
} 
we present evidence of the causal effect of OPORTUNIDADES on increased investments in agricultural and micro-enterprise activities. Having established that cash transfers lead to more investment, section 4 develops a basic model of investment to illustrate the relationship between consumption, transfers and investment that we then estimate empirically. Section 5 provides a series of robustness tests to support our main findings and section 6 concludes.

\section{The Rural OPORTUNIDADES Program}

The Mexican Government established OPORTUNIDADES (originally called PROGRESA) in 1997. The program was designed to alleviate current poverty and break its intergenerational transmission by inducing parents to invest in the human capital of children. In this sense, OPORTUNIDADES was conceived as a temporary program (i.e. over the course of three to four decades), which would become obsolete once the current generation of beneficiary children reaches adulthood.

Cash transfers from OPORTUNIDADES are given to the female head of household ${ }^{7}$, and are conditional on children attending school, family members obtaining preventive medical care through clinic visits and attending "pláticas" or education talks on health related topics. OPORTUNIDADES is the largest conditional cash transfer program of its kind. It distributed approximately 3 billion US dollars to some 5 million beneficiary households in $2004^{8}$.

The cash transfers come in two forms. The first is a bimonthly fixed food stipend conditional on family members obtaining preventive medical care and is intended for families to spend on more and better nutrition. The second type of transfer comes in the form of educational scholarships and is given conditional on children attending school a minimum of $85 \%$ of the time and on not repeating a grade more than twice. Specifically, OPORTUNIDADES provides bimonthly cash scholarships for each child less than 18 years old enrolled in school between the third grade of primary school and the third grade (last) of junior high. High school scholarships are

\footnotetext{
${ }^{7}$ Scholarships for beneficiaries in upper-secondary school can be received by the youth themselves.

${ }^{8}$ www.oportunidades.gob.mx
} 
granted to all beneficiaries younger than 21 years old who are enrolled in school. The educational stipend varies by grade and gender. It rises substantially after graduation from primary school and is higher for girls than boys during junior high and high school. Beneficiary children also receive money for school supplies once or twice a year. There is an upper limit in the total transfer received per household. Table 1 details transfer amounts in October 1997 prices.

When OPORTUNIDADES was first rolled out in rural areas starting in 1997, program eligibility was determined in two stages (Skoufias et al. 2001). First, the program identified underserved or marginalized communities and then identified low-income households within those communities. Selection criteria for marginalized communities were based on the proportion of households living in very poor conditions, identified by using data from the 1995 census (Conteo de Población y Vivienda). For the selection of eligible households within marginalized communities, OPORTUNIDADES conducted a socio-economic survey, the Encuesta de Características Socioeconómicas de los Hogares (ENCASEH). This census of households was used to classify households as eligible for treatment ("poor") or ineligible ("non-poor") using a proxy means test (PMT). Using the 1997 ENCASEH, the original classification scheme designated approximately $52 \%$ of households as eligible ("poor")

All eligible households living in treatment localities were offered OPORTUNIDADES and a majority $(90 \%)$ enrolled in the program. Once enrolled, households received benefits for a threeyear period conditional on meeting the program requirements. New households were not able to enroll until the next certification period which prevented migration into treatment communities for OPORTUNIDADES benefits. Households in rural areas were "recertified" (re-assessed with a proxy means test) after three years on the program to determine future eligibility. If a household was recertified as eligible, it would continue receiving benefits. If not recertified, the household was guaranteed three more years of support followed by three years of transitional support. Thus,

\footnotetext{
${ }^{9}$ Later the Government decided that a subset of the "non-poor" households had been unduly excluded. They expanded the eligibility criteria to include a set of slightly wealthier households in a process called "densification" (Hoddinott and Skoufias 2004).
} 
households could expect a minimum of nine years of benefits upon enrolling in the program (OPORTUNIDADES 2003).

In order to transfer the cash, OPORTUNIDADES had to verify that households actually completed the required health care visits by having medical providers from the public clinics who administered the services certify that the household had completed the requirements. A similar procedure was followed for the cash transfer associated with school attendance. About 1 percent of households were denied the cash transfer for non-compliance.

\section{Experimental Design and Data}

Our analysis takes advantage of the controlled-randomized evaluation design implemented by the Mexican Government to conduct a rigorous impact evaluation of OPORTUNIDADES. Due to budgetary and logistical constraints, the Government was unable to enroll all eligible families simultaneously. Rather, it needed to phase in enrollment over a period of time. For ease of implementation, the Government decided that it would enroll whole communities at a time and that it would enroll them as fast as possible so that no eligible household would be kept out of the program. As a result of this process, the government randomly chose 320 treatment and 186 control communities in seven states for a total of 506 experimental communities. Eligible households in treatment communities began receiving benefits in April of 1998, and eligible households in control communities were not incorporated until November of 1999 nor were they informed that OPORTUNIDADES would provide benefits to them until two months before incorporation.

The data used in this paper comes from household evaluation surveys and administrative records of the amount of money transferred to households. Detailed information on a host of topics was collected in a series of rural evaluation surveys, the Encuesta de Evaluación de los Hogares Rurales (ENCEL). The ENCELs survey all eligible and ineligible households in treatment and control communities. The sub-sample used for the main analysis in this paper is restricted to eligible households classified as poor, although we also use ineligible (non-poor) households for 
robustness checks. There are three rounds of data during which eligible households in control communities did not receive transfers (October 1998, May 1999 and November 1999), and a straightforward comparison of treatments and controls is possible. Once control communities were incorporated into the program at the end of 1999, an additional three rounds of data were collected during which eligible households in both types of communities were receiving benefits (May 2000, November 2000 and November 2003). In addition, baseline data from the 1997 pre-intervention ENCASEH census is used for a total of seven rounds of data between 1997 and 2003.

Our sample consists of 7,658 poor households that were eligible for the program in the 320 treatment communities and 4,644 poor households that were eligible for the program in the 186 control communities (Table 2). We refer to this sample as the "intent to treat" or ITT sample. Baseline data for this sample are described in detail in Table 3A. The sample is well balanced across control and treatment groups. We report the test of difference in means across control and treatment groups, finding no statistically significant differences for 33 out of 35 characteristics measured at baseline. This suggests that the randomization was effective in generating truly exogenous variation in the treatment.

We also conduct the analysis with a second sample designed to estimate the effect of treatment on the treated (TOT). In these analyses, we use the approximately 90 percent of eligible households that actually took up the program, 6,819 treatment households and 4,159 control households that took up the program when offered in late 1999. A potential source of bias arises in the TOT sample if observed and unobserved time varying characteristics are driving the household's decision to participate in the program. We assume the group of controls that took up the program when offered in late 1999 would have taken up the program if offered earlier in 1998. The fact that take up rates amongst treatment and controls are almost identical (90\%) supports this hypothesis (Table 2 and Graph 1). Furthermore, the TOT sample baseline observables are well balanced, with only 1 statistically significant difference out of 35 characteristics tested (Table 3B). 
Given this evidence, we conclude that working with the actual beneficiaries does not introduce selection bias coming from heterogeneous take up responses.

\section{Investment}

In this section, we estimate the effect of OPORTUNIDADES on investments in agriculture and micro-enterprise activities. We show that beneficiary households increase agricultural assets and participation in micro-enterprise activities, suggesting that some of the cash transfer was used for investment in productive assets. Section 3.1 presents the empirical specification based on the randomized design of the OPORTUNIDADES evaluation sample, section 3.2 presents comparisons of means, and sections 3.3 and 3.4 discuss the main investment results.

\subsection{Specification and Identification}

Our analysis exploits the exogenous variation introduced by random assignment of treatment to estimate the effect of OPORTUNIDADES on investment in agricultural production and micro-enterprise activity, the two most common domestic income generating activities in this population. We estimate two types of models: one exploiting the community randomization to obtain average treatment effects, and a second which exploits the variation in transfer amounts to estimate the effect of the size of the transfer on investments.

To estimate the first specification we use the exogenous variation generated by the randomized phasing in of the program. Beneficiary households in treatment communities received transfers for just over a year and a half longer than beneficiary households in control areas. Given the timing of the ENCEL surveys, we first observe treatment households in October 1998, approximately 6 months following the first transfer payment. Treatment households would have received three bimonthly transfer payments by the time of the first follow up survey. Since control communities did not begin receiving payments until November-December of 1999, there are three rounds of data (October 1998, May 1999 and November 1999) where a simple comparison of eligible households in treatment and control communities is possible. 
For these three rounds, we estimate the following reduced form:

$$
A_{i j t}=\alpha_{o}+\alpha_{1} T_{i j}+\sum_{t} \alpha_{2 t} W A V E_{t}+\sum_{k} \beta_{k} X_{i j, 97}+u_{j}+\varepsilon_{i j t},
$$

where $A_{i j t}$ denotes productive assets of household $i$ in community $j$ in period $t ; T_{i j}$ is a binary indicator equal to 1 if eligible household $i$ lives in a treatment community in the ITT specification, or if the household has received benefits in the TOT specification; $W A V E_{t}$ takes on the value 1 in period $t$, and the $X_{i j, 97}$ are household and community characteristics measured at baseline. The error term has two components: an idiosyncratic disturbance, $\varepsilon_{i j t}$, and a community random effect, $u_{j}$, that accounts for the correlation within communities over time. Note that the dependent variable in the analysis is the level of assets and not investment during the period. If the randomization successfully balanced the treatment and control groups, the level of pre-treatment assets would have been the same in treatment and control households (we explicitly test this assumption in section 3.2). Under this assumption, the coefficient $\alpha_{1}$ is the average treatment effect on productive assets.

The second specification takes advantage of the variation in total cumulative transfers introduced both by the randomized phasing in of the program and the variation in the transfer amount based on the demographic structure of the household. The randomization meant that treatment households had been accumulating transfers for about 18 months longer than control households (Graph 1). In addition, households with more children in school and enrolled in higher grades (more female children in higher grades in particular) had higher transfer amounts, and therefore accumulated transfers faster than similar households with fewer children in school or with more male children. Graph 2 illustrates the variation in household demographic structure, plotting shares of households by number of children enrolled in any grade between the third year of primary and the third year of junior high ${ }^{10}$.

\footnotetext{
${ }^{10}$ Households with teenagers enrolled in high school are excluded because high school stipends were granted beginning in the 2001-02 school year (following the experimental period), and because of the low high school enrollment rates (only $33 \%$ of 15 to 21 year olds report being enrolled in high school).
} 
The second specification uses all six rounds of data from 1998 through 2003 to estimate the differential effects of cumulative transfers on productive assets. Cumulative transfer quintiles are constructed for each household-wave observation based on the total transfer amount a household has accumulated at that point in time. These new variables are constructed as indicator variables for the quintile a household belongs to in each round. It is important to note that they are constructed on the distribution of transfers across all waves of data and not within each round. We then use the cumulative transfer quintile dummy variables to estimate the following specification:

$$
A_{i j t}=\alpha_{o}+\sum_{p=1}^{5} \alpha_{1 p} Q_{i j t, p}+\sum_{t} \alpha_{2 t} W A V E_{t}+\sum_{k} \beta_{k} X_{i j, 97}+u_{j}+\varepsilon_{i j t}
$$

where $Q_{i j t, p}$ equals 1 if household $i$ in community $j$ in period $t$ falls in the $p$-th quintile of the total cumulative transfer distribution. We specify the effect of cumulative transfers non-linearly so as to allow for jumps in investment due to the potential lumpiness of certain types of investment.

One potential concern with the specification in equation (2) is that actual total cumulative transfers are determined in part by household decisions to send their children to school. If households decide their children should work instead of going to school, then part of the income generated from work may be invested. In this case, we would obtain a biased estimate of the impact of the transfer amount on investment.

In order to correct for this potential endogeneity we use the potential transfer the household would have received if all eligible children were enrolled in school. To compute potential transfers, we take household composition and children's enrollment status at baseline and apply the program rules, assuming the child progresses one grade per year with no school drop outs and no repetition. Our IV is therefore constructed from pre-intervention household demographic structure interacted with timing of incorporation into the program (which was determined randomly). Since the potential transfer amounts include no household behavioral response but are highly correlated with actual transfers, it is a valid instrument of the actual transfer amounts. We also control for the 
number of household members and share of children directly, so that the IV is not confounded with family composition effects.

Graphs $3 \mathrm{a}$ and $3 \mathrm{~b}$ plot the distributions of the actual and potential current and accumulated transfers, respectively. As shown, the distributions of the potential transfers follow those of the actual transfers very closely. As expected, the potential transfers are an over-estimate of the actual transfers (given non-compliance, administrative delays in payments, etc). The simple correlation amongst them is 0.89 . If we control for time effects and baseline covariates, the potential transfer explains $55.7 \%$ of the total transfer and $65.9 \%$ of the variation of the cumulative transfer. Graph 4 plots mean cumulative transfer by quintile for the distributions of actual and potential cumulative transfers.

\subsection{Comparison of Means}

The dependent variables for agricultural assets come from the six rounds of the ENCEL that contain information on animal ownership and amount of land in use over the 12 months preceding the interview (hectares of land for agriculture, grazing and/or forestry purposes). We define production animals to be those whose meat and/or by-products (milk, cheese, eggs, etc.) are sold and consumed. These include goats and sheep, cattle (cows), poultry (chickens, hens and turkeys), pigs and rabbits. We define draft animals to be those traditionally used for farming (plowing) and/or for transportation purposes. These include donkeys, mules, horses and oxen. We transform all of these animals into "cow equivalents" using the ratio of the price of the animal divided by the price of a cow. Therefore, we create cow-equivalent indices of production and draft animals. Land is measured in hectares and includes all plots used by the household ${ }^{11}$.

The dependent variables for (non-agricultural) micro-enterprises come from five rounds of the ENCEL surveys (October 1998 to December 2000). A set of questions ask the household head whether somebody in that household had engaged in a "self-motivated" non-agricultural activity which generates income during the month before the interview. The list of activities includes

\footnotetext{
${ }^{11}$ A detailed description of the sample and variables is available upon request.
} 
sewing clothes, making food for sale, carpentry and construction, sale of non-food items such as handcrafts, transportation of people or goods in own vehicle, repair of artifacts or machinery, domestic service (wash, iron or cook for a fee), or other activities done on your own. We define micro-enterprise as participation in any of these activities. No micro-enterprise activities were collected in the 1997 baseline survey, and because of lack of comparability (changes in the categories and time frame considered), we do not include the 2003 round.

For the purpose of analysis, we classify households according to the amount of land used and agricultural asset ownership at baseline. We distinguish between: (i) households with no agricultural assets, (ii) landless farms (households reporting no land use but animal ownership), (iii) smaller landed farms (households using at least 3 ha of land for agricultural, grazing or forestry purposes, regardless of animal ownership), and (iv) bigger farms (households using more than 3 ha, regardless of animal ownership). Around one tenth of the sample has no agricultural assets, $31 \%$ of households are landless but have some animals, $45 \%$ have smaller farms and $13 \%$ have bigger farms. We check for balance between treatment and control households within farm size categories in Table $3 \mathrm{~A}$ in the Data Appendix.

With random assignment of communities to treatment and control groups, we would expect that ownership of farm assets at baseline would be equal between the two groups. Then, any subsequent changes could be attributed to the program. In effect, when we compare agricultural assets of treatment and control households in the TOT sample prior to intervention, we find no statistically significant differences in mean values (Table 4 Panel A).

During the experimental period (October 1998 through November 1999), a simple comparison of the mean values for each dependent variable between households in treatment and control communities gives us an estimate of the program impact (see Table 4 Panel B). We report the results both for whether the household had any of the asset type and for the amount of the asset. We observe significant increases in the likelihood of draft and production animal ownership for all households and in particular for households with no agricultural assets (increases in production 
animal ownership only), landless households (increases in draft animal ownership only) and bigger farms (increases in both types of animal ownership). There are significant (at the $10 \%$ level) increases in land use for landless households (including households with no agricultural assets) and significant increases in the number of production animals for landless and smaller farms. Production animals generally require lower capital investments than draft animals. Thus, it is plausible that households with no farm assets initiate animal production by buying small animals that yield relatively quick returns (for example eggs and meat from chickens or turkeys).

For micro-enterprises, the comparison of means between treatment and control households during the experimental period suggests important program effects on the likelihood of engaging in micro-entrepreneurial activity. Specifically, when activities traditionally done by men (construction/carpentry and machinery repair, which are $92 \%$ and $77 \%$ male respectively) are excluded from the dependent variable, households in the treatment group have 58 percent more micro-enterprises than those in the control group. Results hold for landless and smaller farms.

\subsection{Estimated Treatment Effects}

We estimate the effect of OPORTUNIDADES on both the probability of owning an asset and the amount of the asset owned for draft animals, production animals and land. For the probability of having an asset type, we first report the results for the whole sample and then for a sample that is restricted to households that had none of the asset at baseline. Analogously, for the amount of the asset type, we first report the estimate on the whole sample and then restrict the sample to those households with positive levels of the asset at baseline. The probability of owning an asset conditional on having none at baseline provides insight on whether the program induced households to start a farm business (variation at the extensive margin), whereas the estimated impact of the amount of an asset conditional on having some of that asset at baseline tells us about how the program influenced households to expand their already existing farm assets (variation at the intensive margin). 
The results of these analyses are presented in Table 5. In Panel I we report the estimated impact of the program on asset ownership (and land use). Each cell reports the estimated impact of the program on an asset type (columns) using a particular model specification (rows). For each of the asset types listed in the columns, we first report the results using the whole sample and then for the sample restricted to those that did not own any of the assets at baseline. The rows report the empirical specification used. Models A and B in the first two rows report the estimated ITT and TOT impacts, respectively, without controls. Models C and D add baseline household and community controls. The list of controls includes household head and spouse's ages and education, head's ethnicity, household demographic composition and size, baseline assets (home ownership, dirt floor and electricity), and community characteristics (male agricultural wage in the community, distance to large urban center and presence of community work associations). The descriptive statistics for the controls are presented in Tables 3A and 3B.

In Panel I of Table 5 (Model D - TOT with controls), we observe that the probability of draft animal ownership is 2.2 percentage points higher in treatment households than in control households, conditional on no draft animal ownership in 1997. Similarly, treatment households are 6.2 percentage points more likely to own production animals, conditional on no production animal ownership at baseline. Given the average levels of asset ownership for control households in the estimation sample, these coefficients imply that treatment households are $20.2 \%$ more likely to own draft animals and $13.4 \%$ more likely to own production animals than control households. Results are robust to the exclusion of covariates (Model B) and/or inclusion of all intent to treat households (Models A and C). Finally, the 5.2 percentage point (15.7\%) increase in the conditional probability of land use suggests that landless households are acquiring land.

In Model E, we interact the treatment indicator with the level of agricultural assets prior to the intervention. We hypothesize that households with existing assets are more likely to invest more as they have already paid the fixed costs of startup. The estimates from Model E are in line with this hypothesis. Only households owning animals at baseline significantly increase draft animal 
ownership under treatment. Landless households and small farms increase draft animal ownership by 3.5 and 2.9 percentage points respectively (conditional model). On the other hand, treatment households with no agricultural assets at baseline are 9.4 percentage points more likely to increase production animal ownership than control households. Households with no baseline agricultural assets and landless households increase land use by 4.9 to 6.5 percentage points respectively (10\% significance).

Panel II in Table 5 presents the estimated impacts of the program on the amount owned of each asset. Again, there is no difference between the ITT and TOT models with or without controls. Model D shows that conditional on having draft animals at baseline, there is an increase in the number of cow equivalent draft animals of 0.062 cows (or equivalently, 0.15 horses or 0.41 mules) for all households (10\% significance). Households with small farms increase the number of cow equivalent draft animals by 0.078 cows (or equivalently, 0.19 horses or 0.51 mules), conditional on having draft animals at baseline. Production animals increase by 0.125 cow equivalents (significant at the $10 \%$ level), equal to approximately 0.70 goats, 0.79 pigs or 6.76 chickens and/or turkeys. Effects are larger in magnitude for households with big farms at baseline. For big farms in the conditional sample, OPORTUNIDADES increases the number of draft animals by 0.112 cow equivalents ( 0.27 horses or 0.73 mules), and increases the number of production animals by 0.291 cow equivalents (1.63 goats, 1.84 pigs or 15.75 chickens and/or turkeys). Finally, big farms increase land usage by 0.162 hectares on the unconditional sub-sample ${ }^{12}$.

The effect of OPORTUNIDADES on micro-enterprise participation is estimated with a set of probit regressions. Results are presented in Table 6. Models A and B present the average treatment effect when no controls are included, for the ITT and TOT sub-samples, respectively. Models C and D incorporate household and community controls. For this period, treated households

\footnotetext{
${ }^{12}$ For the October 1998, May 1999 and November 2003 rounds of the ENCEL, we have information on land ownership which allows us to classify land into "owned land", if any households member is reported to be the owner; and "non-owned land", if the plot is reported to be rented, borrowed or in tenancy. Results (available upon request) show an increase of approximately 0.034 ha $\left(340 \mathrm{~m}^{2}\right)$ in the use of non-owned land for beneficiary households.
} 
have a 2.5 to 2.8 percentage point higher participation in micro-enterprise activities than control households. Given a mean participation rate in micro-enterprise of $5.9 \%$ by control households over the sample period, treatment households are approximately $42.3 \%$ to $47.7 \%$ more likely to engage in micro-enterprise activity. The last column in Table 6 shows the same set of regressions for predominantly female micro-enterprise activity participation. We find a positive treatment effect of 2.8 percentage points without controls, and 3.0 percentage points with controls, or a $58.9 \%$ increase in the likelihood of having a micro-enterprise ${ }^{13}$.

\subsection{Estimated Transfer Effects}

In Table 7, we present the estimates of the intensity of treatment as measured by the quintile of the accumulated transfer distribution (equation (2)). The results are reported in six panels. The first three panels report the estimated effects of the amount of the transfer on the probability of owning the asset type and the second group of three panels reports the results for the impact on the amount of the asset owned. In all of the panels, Model A shows estimates using the quintiles of the cumulative potential transfer, which can be compared to estimates using the cumulative actual transfer in Model B. Note the similarity in magnitude and significance between estimates in models A and B. Model C repeats Model B using the conditional sample; either not owning the asset at baseline for the probability of ownership models or owning some of the asset at baseline for the amount models. Model D further interacts treatment with baseline farm size.

A noteworthy pattern emerging from Table 7 is that households receiving higher accumulated transfers per wave have a higher likelihood of investing in agricultural assets. Point estimates on each quintile, while positive and increasing with the quintile, are generally significant only at the top quintiles, suggesting a possible threshold in the amount of accumulated transfers needed to start investing. For production animals, significant increases are achieved at lower

\footnotetext{
${ }^{13}$ We have further analyzed female micro-enterprises by activity type (results available upon request). Interestingly, we find large and significant differences in handcraft enterprises amongst treatment and control households, but no differences in domestic services. Handcraft manufacture requires a larger initial capital expenditure than domestic services (which might only imply transportation costs if the jobs are in distant locations) and thus are more likely to be restricted by liquidity constraints.
} 
quintiles. This is not surprising since smaller amounts of money are required to purchase a production animal (a turkey, a goat, etc) than a draft animal (a horse or an ox). The effect per quintile on the probability of land use follows the same general pattern. Effects are larger on the conditional estimates, again suggesting that initially landless households are acquiring more land (Model C). The number of hectares used is positive and increasing with the quintile of cumulative transfers except for the top quintile. One possible explanation for this result is that households might be afraid to lose their eligibility status if they accumulate too many easily verifiable assets. Results are similar when conditioning on baseline farm size (Models D in Table 7).

\section{Consumption}

Section 3 presented evidence that OPORTUNIDADES beneficiaries increased farm production and micro-enterprise activity. In this section, we turn our attention to the effect of these investments on living standards. Specifically, we are interested in the effect of the program on income and consumption. One of the limiting factors in this analysis is that we do not have income data, but rather only consumption. Therefore we need to infer the key structural parameters for a consumption model. The parameters of interest are the marginal propensity to consume and to invest (or save), and the return on these investments. We begin with a discussion of the specification and identification in the context of a simple inter-temporal consumption and investment model $^{14}$. We then describe the estimation and results. We test a number of important identifying assumptions in the next section.

\subsection{Model and Empirical Specification}

In this section we derive the empirical specification for the consumption equation from the set of budget and productive constraints the household faces in the context of an inter-temporal utility maximization model. Consider a setting where household income is derived from a family business and government transfers, and the household is credit constrained. In each period, the household

\footnotetext{
${ }^{14}$ Note that it is beyond the scope of this paper to estimate a full household structural savings and investment behavioral model. Instead, we sketch a simple statistical model which allows us to interpret the reduced form estimates obtained in the empirical analysis.
} 
decides how much of its income is consumed and how much is invested in the family farm or micro-enterprise so that its budget constraint is:

$$
C_{t}=Y_{t}+P T_{t}-I_{t}
$$

where $C_{t}$ is consumption in period $t, Y_{t}$ is income from the household's productive activities, $P T_{t}$ are public transfers, and $I_{t}$ denotes investment.

For simplicity, we will assume that the family business production is a function of business assets, $A_{t}$, and family labor, $L$ :

$$
Y_{t}=\gamma(L) A_{t}+\varepsilon_{t}
$$

where $\varepsilon_{t}$ is a zero mean random productivity shock such as weather or illness. We assume that only family labor is used for production, which is consistent with the data. Moreover, we are not allowing family labor time allocations to be a choice in this model.

Let $\delta$ be the depreciation rate. Then, the household can increase its stock of productive assets through investment, and accumulates assets as follows,

$$
A_{t}=\delta A_{t-1}+I_{t-1}
$$

We assume that households are credit and liquidity constrained. This implies that the maximum amount households can invest in a single period is their income in that period and that investment cannot be negative; i.e.

$$
I_{t} \geq 0
$$

The household chooses consumption and investment to maximize the discounted present value of consumption. The resulting Euler equation at $t$ is:

$$
U^{\prime}\left(C_{t}\right)=\beta \gamma(L) U^{\prime}\left(C_{t+1}\right)+\lambda_{t}\left(I_{t}\right)
$$

where $\lambda_{t}\left(I_{t}\right)$ is the Lagrange multiplier associated with constraint (6). The optimal levels of consumption and therefore investment equate the marginal utility of current consumption to the marginal utility of future consumption plus the marginal cost of the liquidity constraint on 
investment. The solution in (7) provides us with the optimal marginal propensity to consume out of income, which we denote $\alpha_{t}$.

Consider the first two periods that households receive transfers from OPORTUNIDADES.

In this case, the optimal consumption level in the second period after transfers begin is:

$$
C_{t+1}=\alpha \gamma(L) \delta[\delta+\gamma(L)(1-\alpha)] A_{t-1}+\alpha P T_{t+1}+[\alpha \gamma(L)(1-\alpha)] P T_{t}+\alpha \varepsilon_{t+1}+[\alpha \gamma(L)(1-\alpha)] \varepsilon_{t}
$$

where $\alpha$ is the marginal propensity to consume and $(1-\alpha)$ is the marginal propensity to invest ${ }^{15}$. Consumption is a function of initial assets and family labor, current transfers, lagged transfers and productivity shocks. The coefficient on current transfers is just the marginal propensity to consume. The coefficient on lagged transfer consists of three structural parameters. Working backwards, the first is the marginal propensity to invest $(1-\alpha)$, which when multiplied times transfers yields the amount of the transfer invested. The second parameter is the marginal productivity of investment, $\gamma(L)$, which when multiplied times investment yields income earned from the investment. The third parameter is the marginal propensity to consume, $\alpha$, which when multiplied times income yields the amount of income earned from the investment that is consumed.

For each round of data from 1998 through 2003 where there is consumption data available, we estimate (8) as the following reduced form:

$$
C_{i j t}=\phi_{o}+\phi_{1} P T_{i j t}+\phi_{2} \sum_{s=1}^{t} P T_{i j t-s}+\sum_{t} \phi_{3 t} W A V E_{t}+\sum_{k} \pi_{k} X_{i j, 97}+v_{j}+\xi_{i j t}
$$

where $C_{i j t}$ is monthly per capita adult equivalent consumption ${ }^{16}$ of household $i$ living in community $j$ at time $t ; P T_{i j t}$ is the current monthly OPORTUNIDADES transfer per capita; and $\sum_{s=1}^{t} P T_{i j t-s}$ are 6months lagged total per capita cumulative transfers, i.e. the total transfer amount the household had accumulated until six months prior to the current round of the ENCEL survey $(t)$. Since

\footnotetext{
${ }^{15}$ For simplicity, we assumed that the marginal propensity to consume is constant over time. However, if OPORTUNIDADES significantly relaxed the liquidity constraint, the marginal propensity to consume might fall over time. We tested and rejected this assumption against the alternative of a constant marginal propensity to consume.

${ }^{16}$ We define adult equivalent household size as the number of children age 12 or younger times 0.5 plus the number family members older than 12 .
} 
consumption is also a function of initial assets and household labor endowments, we include baseline household demographics, the community wage rate and head and spouse characteristics, i.e. the $X_{i j, 97}{ }^{17}$. As before, the error term is composed of an idiosyncratic disturbance, $\xi_{i j t}$, and a community random effect, $v_{j}$.

The specification in (9) allows us to identify the marginal propensity to consume and the increase in consumption from investment. The marginal propensity to consume, $\alpha$, is just the coefficient on current transfers, $\phi_{1}$. The rate of return in terms of increased income, $\gamma$, is $\phi_{2} / \phi_{1}\left(1-\phi_{1}\right)$, where $\phi_{2}$ is the coefficient on lagged transfers, and the rate of return in terms of consumption is $\phi_{2} /\left(1-\phi_{1}\right)$.

\subsection{Estimated Treatment Effects}

We now turn to the analysis of the effects of current and lagged cumulative transfers on consumption. Our aim here is to determine the proportion of the cash transfer that is consumed directly out of current transfers, with the remainder being saved or invested. We then capture the long run effects of the program on consumption through the total cumulative transfer amount lagged by 6 months, and argue that any increased long run consumption is achieved through productive investments.

We estimate (9) for the 4 rounds of the ENCEL for which we have detailed consumption information, including home produced consumption. As has been previously discussed, because reception of the transfer is conditional on school enrollment, the transfer amount received is endogenous to household behavior. Thus, we instrument current and lagged actual transfers with their "potential" counterparts ${ }^{18}$. The standard errors are clustered at the community level to control for the correlation of the productivity shocks within communities over time.

\footnotetext{
${ }^{17}$ The full list of controls is kept the same as for the investment runs with the exception that baseline household size is replaced with baseline household size adult equivalent for the consumption runs.

18 Separate identification of lagged cumulative transfers from current transfers is possible because treatment households were randomly assigned benefits a year and a half before control households.
} 
The consumption measurement used for the analysis is constructed as total household expenditures on food and non-food items, plus home produced consumption ${ }^{19}$. Expenditures and home produced consumption are separately identifiable in the data. Households are asked about the quantity and expenditures of goods purchased over the week before the interview, as well as how much of their own production of that good was consumed. We use community level prices to impute a value for household production. Previous research on the OPORTUNIDADES program estimates that monetary transfers from the program represent approximately $20 \%$ of pre-program consumption (Hoddinott and Skoufias 2004; Skoufias 2005). The summary statistics presented in Table 8 show a similar result, with the mean transfer amount in treatment households equal to $21 \%$ of consumption in control households. Comparing the consumption levels of households in treatment and control communities, we observe that treatment households consume approximately 22 pesos more per capita per month, representing $61 \%$ of the average per capita monthly transfer of 36 pesos. This simple comparison of consumption levels in treatment and control households suggests that households do not consume the entire transfer amount each month, and that some of the transfer is saved or invested.

Table 9 presents least squares (LS) and two stage least squares (2SLS) estimates of equation (9) for the entire sub-sample of households. Instrumental variable estimates (including controls) on monthly transfers per capita indicate that, on average, 0.884 pesos of each peso transferred are consumed. The coefficient on cumulative transfers is $\hat{\phi}_{2}=0.018$. These results indicate that households consume over four fifths of the transfers directly. The household invests the remaining 0.116 pesos of each peso transferred, and obtains a return of 0.018 on each peso transferred in terms per capita consumption terms. The return on each peso invested $(\hat{\gamma})$ is $15.52 \%$ in terms of consumption and $17.55 \%$ in terms of income.

\footnotetext{
${ }^{19}$ Alternative consumption measures were imputed using quantity consumed times median community prices, and yield comparable results. The consumption measurement used here sums reported expenditures and the imputed value of home production for food and non-food items in a detailed consumption module.
} 
The implied long term effects of the transfers on living standards through the investment pathways are dramatic. In 2003, after five and one-half years on the program, households in the treatment group received an average cumulative transfer of $\$ 3,444$ pesos per capita. Through the increased income from invested transfers, the average beneficiary consumed 62 pesos more per month $^{20}$. Thus, after five and a half years, transfers increased consumption by $34 \%$ through the investment pathway ${ }^{21}$. Since the $34 \%$ increase in consumption is through investment in income generating activities, it should continue even if the household dropped out of the program.

These results also suggested that households were liquidity constrained. The estimated rate of return on investment, $17.55 \%$, is substantially higher than the average annual real interest rate in the economy for the entire period (1997 to 2003), which was approximately $6.1 \%{ }^{22}$. We take this result as evidence that these households face imperfect credit markets, since obtaining investments in productive activities would yield net gains. In fact, access to credit for the poor rural households in our sample is very limited. In the two rounds of the evaluation survey (May and November 1999) where questions on access to credit are asked, only $2.4 \%$ of households report using credit.

\subsection{Heterogeneous Treatment Effects}

Table 10 presents 2SLS estimates of the effects of current and lagged transfers interacted with farm size in 1997, the age of the head of household, head's education, and distance (in Km) to the closest urban center. The purpose of such interactions is to determine whether household heterogeneity affects preferences (the marginal propensity to consume) and/or productivity (the rate of return).

Non-agricultural households (households with no agricultural assets at baseline) have the highest marginal propensity to consume, while the other three types of households have a similar

\footnotetext{
20 "Permanent" rise in consumption estimated as average cumulative transfers per capita for beneficiary households in the treatment group times the coefficient on returns from investment, $\hat{\phi}_{2}$, estimated as 0.018 .

${ }^{21}$ The percentage increase is measured relative to first round of data where consumption data are available. In this survey eligible households in control communities have a real per-capita expenditure of $\$ 183$ pesos.

${ }^{22}$ The annual real interest rate (computed on the 28-day Inter-Bank Equilibrium Interest Rate) was $5.5 \%$ in 1997 and $2.8 \%$ in 2003. The average annual real interest rate for the whole period is $6.1 \%$ (source: Bank of Mexico and National Institute of Geography and Statistics, INEGI). We take this rate as our benchmark since investments are likely to have occurred over the whole period.
} 
marginal propensity to consume, not significantly different from 0.867 . There is no significant difference in the effect of cumulative transfers on consumption either, with a constant return of 0.018 pesos per peso accumulated. Column 3 in Table 10 indicates that the older the head of the household, the lower the estimated marginal propensity to consume, resulting in a larger remainder left for saving or investment (result not statistically significant). However, this reduction in the marginal propensity to consume becomes smaller with age (positive coefficient on the age squared term). As one expects, there is a larger effect on consumption coming from lagged transfers for households with older heads, and once again, this increase becomes smaller over time. Thus, the transfer amount interacted with the age of the head of the household fits a concave function, which is consistent with a life-cycle model.

Column 4 of Table 10 shows that having a positive amount of education reduces the per capita marginal propensity to consume out of current transfers and increases per capita consumption coming from lagged (invested) transfers (the omitted category is no education). Thus, years of education seem to enhance productive activities slightly. Such results are coherent with the effect on age if we assume that basic education has expanded over time in rural communities so that younger people are likely to be more educated than older people. The interaction between distance to an urban center and lagged transfers (Column 5 in Table 10) is negative and significant. Households in more isolated communities may have overall lower return on investments, likely due to the fact that input and output markets are either difficult to access or completely unavailable. The final column of table 10 shows that all the effects are robust to jointly including all interactions in the same specification.

\section{Robustness Tests}

Despite the identification strategy adopted here, our estimates of the marginal propensities

to consume are subject to a number of potential biases or alternative interpretations. Even in a perfect randomized setting, general equilibrium effects that arise as a result of the program may 
drive the changes in household consumption and in saving/investment behavior. In what follows, we discuss a series of potential biases, the reasons why we should worry about them, and how they are resolved in this context.

\subsection{Macro Income and Price Effects}

OPORTUNIDADES infused small rural communities with large amounts of transfers to over half the residents. The transfers could have had multiplier effects on income and cause price inflation in treatment communities. These community macro effects could have caused prices to rise in treatment areas faster than control areas. Therefore, our estimated effects on consumption could be increases in prices rather than in living standards. In addition, it is possible that the observed increases in micro-enterprise and farm activities could be driven by a community macro income effect derived from the presence of OPORTUNIDADES in the community, rather than by increased liquidity from the transfers at the household level.

We address this concern in two ways. First, we compare agricultural wages for males, females and children between treatment and control communities. Second, we compare the consumption levels and investments in micro-enterprise and farm activities of ineligible households in treatment and control communities. Table 11 reports the comparisons of means for community wages between treatment and control communities, and the comparisons of mean consumption and investment levels for ineligible households after the implementation of the program. We find no significant differences between control and treatment areas for any of the variables. Moreover, Hoddinot and Skoufias (2004) find no differences for food prices between treatment and control communities, giving more support to the inexistence of local price and macro income effects.

\subsection{Labor Supply Effects}

OPORTUNIDADES transfers could be taken in leisure by reducing labor supply. If so, income in treatment households would be reduced over time, as would consumption. Everything else held constant, treatment households would experience lower increases in consumption with respect to control households, the larger the transfer received. In this case, our estimate of the 
marginal propensity to consume would be downward biased and so the upper bound for the "real" rate of return will be lower than the one we have considered so far. Parker and Skoufias (2000) study the program effects on time allocation, concluding that OPORTUNIDADES had no effect on adult labor supply. Furthermore, they find no evidence that the program increased leisure time amongst men and women in beneficiary households.

However, OPORTUNIDADES should affect the labor supply of school-age children as it is designed to release them from work so that they can attend school. In fact, Parker and Skoufias $(2000 ; 2001)$ do find evidence of changes in children's labor force participation in salaried and nonsalaried activities, especially for boys; and increases in school attendance. Schultz (2004) also finds positive effects on primary and secondary school enrollment for boys and girls. As explained earlier, we control for this potential bias by instrumenting actual transfers with the potential transfers.

\subsection{Fertility Effects}

Fertility decisions may also be affected by program participation. The program might generate perverse fertility incentives in order to maximize future transfers received. It might also alter the costs and/or benefits of having a child, as well as reduce the cost of fertility control (or increase its knowledge and availability). The effect on consumption is thus ambiguous since it will depend on household size. Moreover, larger households that receive larger transfer amounts might increase consumption through the income effect. Skoufias (2005) summarizes the findings of a series of evaluations on OPORTUNIDADES until the end of 1999. He reports no record of statistical evidence on fertility rates. In any case, any endogenous fertility responses will be accounted for by the use of the potential transfer (computed on baseline household demographics) as an instrument for the actual transfer amount received.

\subsection{Public and Private Transfers}

OPORTUNIDADES transfers might also crowd out private transfers. The reduction in these transfers and therefore consumption implies that we would underestimate marginal propensity 
to consume. Indeed there is some evidence that supports this potential bias. Using only the October 1998 cross-section collected six months after the intervention, Albarran and Attanasio (2002) find that both the likelihood of receiving a private transfer and the amount received -conditional on receiving private transfers, are significantly and negatively affected by the program.

To assess the extent of the potential bias, we have replicated Albarran and Attanasio's results for the 3 periods for which data on private transfers are available (October 1998, November 1999 and November 2000). First, the amount of private transfers is very small as only $7 \%$ of households receive a private transfer in any given period. The estimation results are presented in Table 12. Panel AI reports the effect of OPORTUNDADES on receiving any private transfer and Panel AII reports the estimated effects on the amount of the private transfer received. We estimate four specifications of the OPORTUNIDADES treatment: in the first row we report the results with a OPORTUNIDADES treatment dummy, in the second row we replace the treatment dummy with the potential OPORTUNIDADES transfer amount, in the third row we add potential transfers squared, and in the fourth row we instrument actual OPORTUNIDADES transfers and actual transfers squared with potential transfers and potential transfers squared. We find that the transferred squared models have significant effects, with the marginal effect size falling with the transfer amount.

The same argument could be made for other public transfers. To test this hypothesis, we estimated the effects of OPORTUNIDADES transfers on other public transfers and report the results in Panels BI and BII in Table 12. We find results similar to the private transfer effects.

To test the robustness of our main results to the effect of OPORTUNIDADES on private and other public transfers, we estimate a variant of the consumption equation (9) by adding private and other public transfers to OPORTUNIDADES transfers. If the coefficients on current transfers and lagged cumulative transfers do not change by adding private and other transfers, then we will conclude that there is no bias. The results are presented in Panels A and B of Table 13, for private and other public transfers respectively. The first column in Panel A, estimates the original 
specification with only OPORTUNIDADES transfers in equation (9) using the data only from the waves that collected both private transfers and other public transfers using potential transfers as the instrument. The second column reports the results when private transfers are added to OPORTUNIDADES transfers. There is no difference between the estimated coefficients in the two models. Column 3 reports the results when we additionally add other public transfers to the OPORTUNIDADES and private transfers. Again there are no differences. In Panel B we reestimate the specifications in Panel A using only other public transfers. The first column reports the base results using only OPORTUNIDADES transfers on data from the waves that collected other public transfers. The second column adds in other public transfers. There is no difference between columns 1 and 2 in Panel B. Finally, column 3 controls for whether the family also receives a public food basket. Again, the estimated coefficients do not change. These results imply that our estimates are not biased due to the exclusion of public and private transfers from the analysis.

\subsection{Health Effects}

We also test the possibility that beneficiary productivity and consumption increased through improvements in health brought on by participation in OPORTUNIDADES. Panel CI of Table 12 estimates the effect of treatment on health, measured by activities of daily living (ADL) ${ }^{23}$. We show that the program does have small positive effect on health. Given this potential pathway, we again estimate our consumption model controlling for health status (ADL) of the head of household on a limited sub-sample where health data are available. The results are presented in Panel $\mathrm{C}$ of Table 13, and again we find that the estimated coefficients on current and cumulative lagged transfers do not change controlling for ADLs. This suggests that our main results are not biased by not controlling for health.

\subsection{Length of Benefits Expectations}

\footnotetext{
23 Activity of Daily Living measurements are based on an individuals' self-rating of ability to engage in normal daily activities, including ability to carry out vigorous and moderate activities, ability to carry groceries, ability to lift a piece of paper off the ground, ability to walk more than $2 \mathrm{~km}$ and ability to use the bathroom and bathe unassisted.
} 
Friedman's (1957) Permanent Income Hypothesis (PIH) contended that permanent income and not current income was the relevant determinant of consumption, and that permanent consumption was proportional to permanent income (the proportionality hypothesis, which implies that the permanent income elasticity is unity $)^{24}$. Such a model would suggest that the marginal propensity to consume out of permanent income should be close to 1 , and the marginal propensity to consume from transitory income should be close to 0 . The implication of the PIH for our results is that if beneficiary households view the transfers as transitory, then they would save most of them; if they view them as permanent, then they would consume most of them.

The proportionality hypothesis and its major implications regarding growth and equity in developing countries have been tested many times, with ambiguous results. For example, Bhalla (1979) finds an estimated marginal propensity to consume out of permanent income of 0.61 and an elasticity of 0.79 (and significantly different from 1) using data from rural India. Wolpin (1982) estimates permanent income elasticities in the range of 0.91 to 1.02 for India as well and concludes that "whether or not it is unity, the permanent income elasticity of consumption may be closer to unity than suggested by previous research”. Musgrove (1979) estimates 0.881 for urban Colombia, 0.896 for urban Ecuador, and, 0.776 for urban Peru; all significantly different from 1. Finally, Paxson (1992) estimates marginal propensities to consume from 0.56 to 0.84 out of permanent income, being significantly different from 1 ; and from 0.17 to 0.27 out of transitory income for rice farmers in Thailand.

Our estimate of the marginal propensity to consume out of current transfers is 0.88 . In view of the estimated magnitudes of marginal propensities to consume in the development literature, we are inclined to think that the rural Mexican households studied here perceive the OPORTUNIDADES transfer as a source of permanent income. Indeed, households know that once they start receiving the benefit they will continue to receive it for at least 9 years provided they

\footnotetext{
${ }^{24}$ The Modigliani-Brumberg life cycle hypothesis ( $\left.\mathrm{LCH}\right)$ reaches analogous conclusions.
} 
comply with the program requirements. Thus, their expectations regarding the length of the benefits are likely to be rather long term.

\subsection{Precautionary Savings}

We have argued that the evidence on farming and micro-enterprise investment responds to an alleviation of risk aversion and liquidity and credit constraints by the program. However, in an uncertain environment, one might expect households to accumulate wealth to smooth consumption over unexpected shocks. This motive is stronger the higher the uncertainty faced by consumers (Carroll and Kimball 1996). Moreover, if their banking services are scarce, savings are likely to take the form of assets such as land and livestock. For instance, Ravallion and Chen (2005) show that much of the impact of an anti-poverty program in Southwest China did not occur through consumption, but rather through savings, since participants treated income from the program as temporary. If the increase in farm asset ownership, farming and micro-enterprise we observe here is due primarily to precautionary savings rather than investment behavior, the expected increases in long run living standards may not be sustained if households stop saving when the transfer is removed.

To rule this possibility out, we test for the existence of a precautionary motive and how the existence of OPORTUNIDADES affected precautionary savings. We estimate agricultural assets (animal ownership and land usage) in 2003 as a function of adverse shocks in the community and the accumulated actual transfer amount received by the household. We construct the history of shocks from natural causes (principally droughts and plagues) from early 1997 to late 2000 and categorize a community as a "high risk area" if it has suffered more than eight shocks during this period $^{25}$. If there is a precautionary motive, then households in riskier areas (with a larger shock history) should have larger investments in agricultural assets in 2003. A dummy for high risk area is interacted with the accumulated transfer amount. If beneficiary households are using part of the

\footnotetext{
${ }^{25}$ The number of shocks per community in this period varies from 0 to 13 , with a median of 5 shocks and an average of 5.41 shocks. The proportion of treatment and control communities in high risk areas is the same as the proportion of treatment and control communities in the sample. However, control communities tend to report a larger number of shocks than treatment communities.
} 
OPORTUNIDADES transfer for precautionary savings the estimated coefficient on this term should be positive. The coefficient on accumulated actual transfers, which we instrument with its potential counterpart, is simply the "per peso" treatment effect.

Results are shown in Panel A of Table 14 for a linear specification in transfers and in Panel B for a quadratic specification. Production animals and land are the channels of wealth accumulation used by these households to ensure their future income. We find that households living in riskier areas are more likely to use land and have production animals, suggesting a precautionary savings motive. However, none of the OPORTUNIDADES money is used with precautionary motives. In fact, the interaction term is negative and significant for land and production animals suggesting that beneficiary households in riskier areas lower their precautionary savings. We find a similar effect for draft animals once we introduce a quadratic term for the transfer amount. Households in treatment areas may be better insured against future adversities because households view the transfer as a permanent source of income. Thus, this analysis rejects the precautionary savings hypothesis as an alternative explanation for the investments results.

\section{Conclusion}

The analysis conducted in this study provides evidence that cash transfer payments from the OPORTUNIDADES program increase consumption not only through direct expenditures out of current transfers, but also through the income generated from investing part of the transfers in farms and micro-enterprises. Beneficiary households experience large increases in participation in microenterprise activities and increased investments in farm assets and agricultural activities. Furthermore, households that receive the largest transfers are most likely to invest.

Conditional cash transfer programs such as OPORTUNIDADES are designed to alleviate short-term poverty while investing in the human capital of the next generation. The positive benefits of this type of intervention are well established, including increased caloric intake, better health and nutrition, and higher school enrollment for children. This increased human capital is expected to play an important role in breaking the cycle of poverty for younger generations. 
However, this paper shows that there are also more immediate implications of cash transfers for alleviating long-term poverty for the current generation of beneficiary households. Cash transfers have the potential to increase income permanently by facilitating investments in productive activities. Furthermore, we argue that the primary mechanisms for achieving this result are through reduced liquidity constraints and decreased risk aversion.

Although we do not argue that cash transfer programs are necessarily the most desirable policy for promoting micro-enterprise or farm investments for poor households in rural areas, it is clear that increased entrepreneurial activity brought on by cash transfers have increased the potential for self-sufficiency. The results presented here suggest that a permanent rise in consumption through increased economic activity may ultimately reduce long-run welfare dependence and permit beneficiary households to attain a higher standard of living that can be sustained even in the absence of the transfer program. Further understanding of the mechanisms through which cash transfers boost productive investments (softening of liquidity and/or credit constraints, reduction of risk aversion, insurance role) is crucially important in the determination and design of future policies to be undertaken, such as micro-lending, business incentives and advising or the provision of insurance schemes, for the alleviation of poverty. 


\section{$\underline{\text { References }}$}

Aghion, Philippe and Patrick Bolton. 1997. "A Theory of Trickle-Development". The Review of Economic Studies, 64(2):151-172.

Albarran, Pedro and Orazio Attanasio. 2002. "Do Public Transfers Crowd out Private Transfers? Evidence from a Randomized Experiment in Mexico". WIDER discussion paper 2002/6.

Banerjee, Abhijit. 2004. "Contracting Constraints, Credit Markets, and Economic Development" in Advances in Economics and Econometrics: Theory and Applications, VIII World Congress of the Econometric Society, vol. 3: 1-46, Mathias Dewatripont, Lars P. Hansen and Stephen J. Turnovsky, eds. Cambridge University Press.

Banerjee, Abhijit and Andrew F. Newman. 1993. "Occupational Choice and the Process of Development”. Journal of Political Economy, 101(2):274-298.

Banco de México. 2006. www.banxico.org.mx

Bhalla, Surjit S. 1979. "Measurement Errors and the Permanent Income Hypothesis: Evidence from Rural India". American Economic Review, 69(3):295-307.

Carroll, Christopher D. and Miles S. Kimball. 1996. "On the Concavity of the Consumption Function". Econometrica, 64(4):981-992.

Friedman, Milton. 1957. A Theory of the Consumption Function, Princeton N.J. Princeton University Press.

Hall, Robert E. 1978. "Stochastic Implications of the Life Cycle-Permanent Income Hypothesis: Theory and Evidence". Journal of Political Economy, 86(6):971-987.

Hoddinott, John and Emmanuel Skoufias. 2004. "The Impact of OPORTUNIDADES on Consumption". Economic Development and Cultural Change, 53(1):37-61.

Instituto Nacional de Estadística, Geografía e Informática (INEGI). 2006. www.inegi.gob.mx

Lindh, Thomas and Henry Ohlsson. 1998. "Self-employment and wealth inequality". Review of Income and Wealth, 44(1):25-42.

Lloyd-Ellis, Huw and Dan Bernhardt. 2000. "Enterprise, Inequality and Economic Development". The Review of Economic Studies, 67(1):147-168.

McKenzie, David and Christopher Woodruff. 2006. "Do Entry Costs Provide an Empirical Basis for Poverty Traps? Evidence from Mexican Microenterprises". Economic Development and Cultural Change, forthcoming.

Modigliani, Franco and Richard H. Brumberg. 1954. "Utility Analysis and the Consumption Function: An Interpretation of Cross-Section Data" in Post Keynesian Economics, Kenneth K. Kurihara ed., New Brunswick:388-436.

Moffit, Robert. 1992. "Incentive Effects of the U.S. Welfare System: A Review". Journal of Economic Literature, 30(1):1-61.

Musgrove, Philip. 1979. "Permanent Household Income and Consumption in Urban South America". American Economic Review, 69(3):355-368.

OPORTUNIDADES. 2003. "Reglas de Operación 2003”. www.progresa.gob.mx

OPORTUNIDADES. 2006: www.oportunidades.gob.mx

Parker, Susan W. and Emmanuel Skoufias. 2000. "Final Report: The Impact of PROGRESA on Work, Leisure, and Time Allocation". Final Report, International Food Policy Research Institute, Washington D.C.

Parker, Susan W. and Emmanuel Skoufias. 2001. "Conditional Cash Transfers and their Impact on Child Work and School Enrollment: Evidence from the PROGRESA Program in Mexico". Economía, 2:45-96.

Paxson, Christina. 1992. "Using Weather Variability to Estimate the Response of Savings to Transitory Income in Thailand". American Economic Review, 82(1):15-33.

Ravallion, Martin and Shaohua Chen. 2005. "Hidden Impact? Household Saving in Response to a Poor-Area Development Project". Journal of Public Economics, 89(11-12):2183-2204. 
Sadoulet, Elisabeth, Alain de Janvry and Benjamin Davis. 2001. "Cash Transfer Programs with Income Multipliers: PROCAMPO in Mexico". World Development, 29(6):1043-1056.

Schultz, Paul. 2004. "School Subsidies for the Poor: Evaluating the Mexican PROGRESA Poverty Program". Journal of Development Economics, 74(1):199-250.

Skoufias, Emmanuel. 2005. "PROGRESA and Its Impacts on the Welfare of Rural Households in Mexico", International Food Policy Research Institute Research Report 139, Washington D.C.

Skoufias, Emmanuel, Benjamin Davis and Sergio de la Vega. 2001. "Targeting the Poor in Mexico: An Evaluation of the Selection of Households into PROGRESA". World Development, 29(10):1768-1784.

Todd, Petra E. 2004. "Technical Note on Using Matching Estimators to Evaluate the OPORTUNIDADES Program for Six Year Follow-up Evaluation of OPORTUNIDADES in Rural Area". Mimeo, University of Pennsylvania.

Wolpin, Kenneth I. 1982. "A New Test of the Permanent Income Hypothesis: The Impact of Weather on the Income and Consumption of Farm Households in India". International Economic Review, 23(3):583-594.

Woodruff, Christopher and Rene Zenteno. 2001. "Remittances and Microenterprises in Mexico". University of California at San Diego, Graduate School of International Relations and Pacific Studies Working Paper.

Yang, Dean. 2005. "International Migration, Human Capital, and Entrepreneurship: Evidence from Philippine Migrants' Exchange Rate Shocks”. World Bank Policy Research Working Paper No. 3578, The World Bank, Washington D.C. 
APPENDIX 1 -TABLES

Table 1: OPORTUNIDADES Monthly Transfer Amounts at Baseline (October 1997)

\begin{tabular}{|c|c|c|c|c|}
\hline Transfer Component & Level & Grade & Boys & Girls \\
\hline \multirow[t]{10}{*}{ Education Stipend } & Primary School & 3rd year & 60 & 60 \\
\hline & & 4 th year & 70 & 70 \\
\hline & & 5 th year & 90 & 90 \\
\hline & & 6 th year & 120 & 120 \\
\hline & Junior High School & 1st year & 175 & 185 \\
\hline & & 2nd year & 185 & 205 \\
\hline & & 3rd year & 195 & 225 \\
\hline & High School $^{1}$ & 1st year & 470 & 540 \\
\hline & & 2nd year & 505 & 575 \\
\hline & & 3rd year & 535 & 610 \\
\hline \multirow[t]{4}{*}{ School Supplies Stipend } & Primary, 1rst payment & & 80 & 80 \\
\hline & Primary, 2nd payment & & 40 & 40 \\
\hline & Junior High School & & 150 & 150 \\
\hline & High School $^{1}$ & & 240 & 240 \\
\hline Nutritional Stipend (per family) & & & \multicolumn{2}{|c|}{90} \\
\hline Transfer Cap I (per family) ${ }^{2}$ & & & \multicolumn{2}{|c|}{550} \\
\hline Transfer Cap II (per family) $^{3}$ & & & \multicolumn{2}{|c|}{700} \\
\hline
\end{tabular}

Source: OPORTUNIDADES (www.oportunidades.gob.mx). Transfer amounts adjusted for inflation every semester according to the Consumer Price Index published by the Bank of Mexico.

${ }^{1}$ High school stipends only granted beginning in the second semester of 2001 (July 2001).

${ }^{2}$ Transfer Cap I is the maximum transfer amount awarded for basic education (primary school and junior high) and nutrition.

${ }^{3}$ Transfer Cap II is the maximum transfer amount given for high school and nutrition.

Table 2: Sample Sizes and Take-Up Rates ${ }^{1}$

\begin{tabular}{|c|c|c|c|c|c|c|}
\hline \multirow[b]{3}{*}{ Sample of Eligible (Poor) Households } & \multicolumn{2}{|c|}{ Treatment } & \multicolumn{2}{|c|}{ Control } & \multicolumn{2}{|c|}{ All } \\
\hline & $\mathbf{N}$ & $\%$ & $\mathbf{N}$ & $\%$ & $\mathbf{N}$ & $\%$ \\
\hline & & & & & & \\
\hline Number Non Take-Up Households & 839 & 10.96 & 485 & 10.44 & 1324 & 10.76 \\
\hline Number Take-Up Households (Actually Treated -TOT) & 6,819 & 89.04 & 4,159 & 89.56 & 10,978 & 89.24 \\
\hline Total Number of Households (Intent to Treat -ITT) & 7,658 & & 4,644 & & 12,302 & \\
\hline Number of Communities & 320 & 63.24 & 186 & 36.76 & 506 & \\
\hline
\end{tabular}

${ }^{1}$ Take-up control households have received at least one bimonthly payment by the time all eligible households should have been incorporated (November 2000). Take-up treatment households must have received their first payment before any eligible control household is phased into the program (November 1999).

${ }^{2}$ We drop 116 households that receive a total transfer amount higher than the maximum they could have potentially received according to their household demographics and treatment status. Households with heads and/or head's spouses younger than 13 or older than 90 also dropped. Drop outs are balanced between the treatment and control samples. 
Table 3A: Test of Equality of Means between Potential Treatments and Potential Controls Prior to Program Implementation Sub-Sample of Original Poor at Baseline (October 1997) -Intent to Treat (ITT)

\begin{tabular}{|c|c|c|c|c|c|c|c|}
\hline \multirow[b]{3}{*}{ Intent to Treat Sub-Sample (ITT) -Explanatory Variable } & \multicolumn{3}{|c|}{ Treatment Group } & \multicolumn{3}{|c|}{ Control Group } & \multirow[b]{2}{*}{ t-stat } \\
\hline & $\mathbf{N}$ & Mean & SD & $\mathbf{N}$ & Mean & SD & \\
\hline & & & & & & & \\
\hline \multicolumn{8}{|l|}{ Head's Characteristics } \\
\hline$\overline{\text { Age Household Head }}$ & 7655 & 41.95 & 14.133 & 4643 & 42.33 & 14.521 & -0.943 \\
\hline Female Head =1 & 7658 & 8.16 & 0.274 & 4644 & 8.40 & 0.277 & -0.377 \\
\hline Indigenous Head =1 & 7646 & 41.90 & 0.493 & 4636 & 43.70 & 0.496 & -0.324 \\
\hline Head's Education (Years) & 5249 & 4.06 & 2.306 & 3143 & 3.95 & 2.250 & 1.148 \\
\hline Never Attended School (Head of Household $)=1$ & 7634 & 31.44 & 0.464 & 4637 & 32.65 & 0.469 & -0.541 \\
\hline Primary School Not Completed (Head of Household) $=1$ & 7634 & 46.28 & 0.499 & 4637 & 46.75 & 0.499 & -0.275 \\
\hline Primary School Completed (Head of Household $)=1$ & 7634 & 16.94 & 0.375 & 4637 & 15.59 & 0.363 & 0.988 \\
\hline More than Primary School (Head of Household) $=1$ & 7634 & 5.34 & 0.225 & 4637 & 5.00 & 0.218 & 0.516 \\
\hline \multicolumn{8}{|l|}{ Spouse's Characteristics } \\
\hline Age Spouse of Head & 6713 & 36.27 & 12.225 & 4074 & 36.17 & 12.223 & 0.296 \\
\hline Spouse's Education (Years) & 4291 & 4.16 & 2.124 & 2551 & 4.21 & 2.243 & -0.603 \\
\hline Never Attended School (Head's Spouse) $=1$ & 6700 & 36.18 & 0.481 & 4067 & 37.35 & 0.484 & -0.411 \\
\hline Primary School Not Completed (Head's Spouse) $=1$ & 6700 & 41.64 & 0.493 & 4067 & 40.69 & 0.491 & 0.477 \\
\hline Primary School Completed (Head's Spouse) $=1$ & 6700 & 18.37 & 0.387 & 4067 & 16.97 & 0.375 & 0.986 \\
\hline More than Primary School (Head's Spouse) =1 & 6700 & 3.81 & 0.191 & 4067 & 4.99 & 0.218 & $-1.953+$ \\
\hline \multicolumn{8}{|l|}{ Main Entrepreneur's Characteristics } \\
\hline$\overline{\text { Age Main Entrepreneur in the Household }}$ & 823 & 0.53 & 0.499 & 338 & 0.54 & 0.499 & -0.178 \\
\hline Education Years Main Entrepreneur in the Household & 818 & 0.35 & 0.477 & 335 & 0.36 & 0.480 & -0.208 \\
\hline Female Main Entrepreneur in the Household =1 & 818 & 2.78 & 2.771 & 335 & 2.61 & 2.582 & 0.676 \\
\hline Main Entrepreneur is the (likely) Beneficiary Mother $=1$ & 822 & 40.29 & 13.919 & 338 & 40.25 & 14.299 & 0.040 \\
\hline \multicolumn{8}{|l|}{ Household Characteristics } \\
\hline$\overline{\text { Presence of Children } 0 \text { to } 7}=1$ & 7645 & 75.36 & 0.431 & 4639 & 77.04 & 0.421 & -1.396 \\
\hline Presence of Children 8 to $17=1$ & 7645 & 69.01 & 0.462 & 4639 & 69.54 & 0.460 & -0.472 \\
\hline Presence of Adult Men 18 to $54=1$ & 7645 & 83.69 & 0.369 & 4639 & 83.75 & 0.369 & -0.057 \\
\hline Presence of Adult Female 18 to $54=1$ & 7645 & 90.26 & 0.297 & 4639 & 90.80 & 0.289 & -0.699 \\
\hline Presence of Adults Older than $55=1$ & 7644 & 27.00 & 0.444 & 4639 & 27.20 & 0.445 & -0.177 \\
\hline Household Size & 7658 & 5.91 & 2.433 & 4644 & 5.94 & 2.413 & -0.457 \\
\hline Home Ownership =1 & 7655 & 93.39 & 0.248 & 4643 & 92.10 & 0.270 & 1.488 \\
\hline Dirt Floor $=1$ & 7641 & 73.17 & 0.443 & 4630 & 75.72 & 0.429 & -1.015 \\
\hline Electricity =1 & 7653 & 57.65 & 0.494 & 4642 & 60.58 & 0.489 & -0.684 \\
\hline No Agricultural Assets $=1$ & 7634 & 10.40 & 0.305 & 4629 & 11.67 & 0.321 & -1.047 \\
\hline Landless Farms $=1$ & 7634 & 10.40 & 0.305 & 4629 & 11.67 & 0.321 & -1.047 \\
\hline Small Landed Farms $=1$ & 7634 & 30.59 & 0.461 & 4629 & 32.45 & 0.468 & -0.828 \\
\hline \multirow[t]{2}{*}{ Big Farms $=1$} & 7634 & 46.86 & 0.499 & 4629 & 40.94 & 0.492 & $2.229 *$ \\
\hline & 7634 & 12.16 & 0.327 & 4629 & 14.95 & 0.357 & -1.876 \\
\hline \multicolumn{8}{|l|}{ Community Characteristics } \\
\hline Village Associations (Community Work) & 7658 & 87.84 & 0.327 & 4644 & 87.75 & 0.328 & 0.021 \\
\hline Minimum Distance to Large Urban Centre $(\mathrm{Km})$ & 7658 & 107.73 & 41.361 & 4644 & 105.11 & 43.721 & 0.522 \\
\hline Monthly Community Agricultural Male Wage & 4426 & 573.86 & 172.005 & 2781 & 585.23 & 172.115 & -0.463 \\
\hline
\end{tabular}


Table 3B: Test of Equality of Means between Actual Treatments and Actual Controls Prior to Program Implementation Sub-Sample of Original Poor at Baseline (October 1997) -Treatment on the Treated (TOT)

\begin{tabular}{|c|c|c|c|c|c|c|c|}
\hline \multirow[b]{3}{*}{$\begin{array}{l}\text { Treatment on the Treated Sub-Sample (TOT) } \\
\text {-Explanatory Variables }\end{array}$} & \multicolumn{3}{|c|}{ Treatment Group } & \multicolumn{3}{|c|}{ Control Group } & \multirow[b]{2}{*}{ t-stat } \\
\hline & $\mathbf{N}$ & Mean & SD & $\mathbf{N}$ & Mean & SD & \\
\hline & & & & & & & \\
\hline \multicolumn{8}{|l|}{ Head's Characteristics } \\
\hline$\overline{\text { Age Household Head }}$ & 6818 & 42.01 & 13.898 & 4158 & 42.49 & 14.381 & -1.140 \\
\hline Female Head =1 & 6819 & 7.86 & 0.269 & 4159 & 7.89 & 0.270 & -0.042 \\
\hline Indigenous Head =1 & 6809 & 41.72 & 0.493 & 4151 & 43.97 & 0.496 & -0.403 \\
\hline Head's Education (Years) & 4745 & 4.03 & 2.268 & 2841 & 3.91 & 2.206 & 1.275 \\
\hline Never Attended School (Head of Household) $=1$ & 6797 & 30.38 & 0.460 & 4154 & 32.04 & 0.467 & -0.796 \\
\hline Primary School Not Completed (Head of Household) $=1$ & 6797 & 47.21 & 0.499 & 4154 & 47.64 & 0.500 & -0.257 \\
\hline Primary School Completed (Head of Household) $=1$ & 6797 & 17.18 & 0.377 & 4154 & 15.53 & 0.362 & 1.172 \\
\hline More than Primary School (Head of Household) =1 & 6797 & 5.22 & 0.223 & 4154 & 4.79 & 0.214 & 0.668 \\
\hline \multicolumn{8}{|l|}{ Spouse's Characteristics } \\
\hline Age Spouse of Head & 6037 & 36.43 & 12.114 & 3693 & 36.47 & 12.120 & -0.111 \\
\hline Spouse's Education (Years) & 3917 & 4.12 & 2.090 & 2322 & 4.15 & 2.160 & -0.287 \\
\hline Never Attended School (Head's Spouse) $=1$ & 6027 & 35.26 & 0.478 & 3687 & 37.08 & 0.483 & -0.669 \\
\hline Primary School Not Completed (Head's Spouse) $=1$ & 6027 & 42.49 & 0.494 & 3687 & 41.58 & 0.493 & 0.464 \\
\hline Primary School Completed (Head's Spouse) =1 & 6027 & 18.57 & 0.389 & 3687 & 16.79 & 0.374 & 1.235 \\
\hline More than Primary School (Head's Spouse) =1 & 6027 & 3.68 & 0.188 & 3687 & 4.56 & 0.209 & -1.451 \\
\hline \multicolumn{8}{|l|}{ Main Entrepreneur's Characteristics } \\
\hline Age Main Entrepreneur in the Household & 760 & 40.38 & 13.964 & 318 & 40.42 & 14.405 & -0.035 \\
\hline Education Years Main Entrepreneur in the Household & 757 & 2.77 & 2.764 & 315 & 2.64 & 2.555 & 0.519 \\
\hline Female Main Entrepreneur in the Household $=1$ & 761 & 53.35 & 0.499 & 318 & 53.77 & 0.499 & -0.061 \\
\hline Main Entrepreneur is the (likely) Beneficiary Mother $=1$ & 757 & 35.54 & 0.479 & 315 & 35.87 & 0.480 & -0.069 \\
\hline \multicolumn{8}{|l|}{ Household Characteristics } \\
\hline Presence of Children 0 to $7=1$ & 6810 & 75.89 & 0.428 & 4157 & 77.24 & 0.419 & -1.101 \\
\hline Presence of Children 8 to $17=1$ & 6810 & 70.47 & 0.456 & 4157 & 70.99 & 0.454 & -0.435 \\
\hline Presence of Adult Men 18 to $54=1$ & 6810 & 84.33 & 0.364 & 4157 & 84.44 & 0.363 & -0.103 \\
\hline Presence of Adult Female 18 to $54=1$ & 6810 & 91.17 & 0.284 & 4157 & 91.46 & 0.280 & -0.378 \\
\hline Presence of Adults Older than $55=1$ & 6810 & 26.77 & 0.443 & 4157 & 27.54 & 0.447 & -0.662 \\
\hline Household Size & 6819 & 6.00 & 2.416 & 4159 & 6.04 & 2.405 & -0.583 \\
\hline Home Ownership =1 & 6816 & 93.87 & 0.240 & 4158 & 92.83 & 0.258 & 1.199 \\
\hline Dirt Floor $=1$ & 6803 & 72.59 & 0.446 & 4145 & 75.49 & 0.430 & -1.116 \\
\hline Electricity $=1$ & 6815 & 58.94 & 0.492 & 4158 & 61.21 & 0.487 & -0.529 \\
\hline No Agricultural Assets $=1$ & 6798 & 9.55 & 0.294 & 4145 & 10.78 & 0.310 & -1.012 \\
\hline Landless Farms $=1$ & 6798 & 30.77 & 0.462 & 4145 & 32.06 & 0.467 & -0.570 \\
\hline Small Landed Farms $=1$ & 6798 & 47.16 & 0.499 & 4145 & 42.17 & 0.494 & $1.84+$ \\
\hline Big Farms =1 & 6798 & 12.52 & 0.331 & 4145 & 14.98 & 0.357 & -1.685 \\
\hline \multicolumn{8}{|l|}{ Community Characteristics } \\
\hline Village Associations (Community Work) & 6819 & 89.18 & 0.311 & 4159 & 87.21 & 0.334 & 0.432 \\
\hline Minimum Distance to Large Urban Centre (Km) & 6819 & 107.53 & 41.857 & 4159 & 105.06 & 43.780 & 0.486 \\
\hline Monthly Community Agricultural Male Wage & 4006 & 573.79 & 170.117 & 2498 & 579.80 & 163.320 & -0.249 \\
\hline
\end{tabular}

Notes: +significant at $10 \%$, *significant at $5 \%$, **significant at $1 \%$.T-stat of differences in means computed clustering SE at the community level. Mean of dichotomous variables expressed in percentages. 
Table 4: Exogeneity Test and Average Treatment Effect -Test of Equality of Means between Actual Treatments and Actual Controls Sub-Sample of Original Poor -Treatment on the Treated (TOT)

\begin{tabular}{|c|c|c|c|c|c|c|c|}
\hline \multirow{3}{*}{ A. Exogeneity Test -Dependent Variables at Baseline (1997) } & \multicolumn{3}{|c|}{ Treatment Group } & \multicolumn{3}{|c|}{ Control Group } & \multirow[b]{2}{*}{ t-stat } \\
\hline & $\mathbf{N}$ & Mean & SD & $\mathbf{N}$ & Mean & SD & \\
\hline & & & & & & & \\
\hline \multicolumn{8}{|l|}{ Al. Entire Sub-Sample } \\
\hline Draft Animals Ownership & 6819 & 35.15 & 0.477 & 4159 & 32.53 & 0.469 & 1.109 \\
\hline Production Animals Ownership & 6817 & 81.90 & 0.385 & 4158 & 82.56 & 0.379 & -0.376 \\
\hline Land Use & 6819 & 59.77 & 0.490 & 4159 & 57.30 & 0.495 & 0.856 \\
\hline Number Draft Animals $\dagger$ & 2391 & 0.98 & 1.999 & 1350 & 0.89 & 1.422 & 0.874 \\
\hline Number Production Animals $\dagger$ & 5576 & 1.25 & 2.281 & 3425 & 1.23 & 2.356 & 0.236 \\
\hline Number Hectares Used $\dagger$ & 4057 & 2.68 & 2.759 & 2370 & 2.94 & 2.851 & -1.564 \\
\hline \multicolumn{8}{|l|}{ AIII. Landless Households in $97=1$} \\
\hline Draft Animals Ownership & 2092 & 26.00 & 0.439 & 1329 & 22.72 & 0.419 & 1.285 \\
\hline Production Animals Ownership & 2092 & 96.99 & 0.171 & 1329 & 97.07 & 0.169 & -0.097 \\
\hline Number Draft Animals $\dagger$ & 543 & 0.75 & 2.714 & 301 & 0.56 & 0.913 & 1.437 \\
\hline Number Production Animals $†$ & 2026 & 0.76 & 1.494 & 1287 & 0.70 & 1.448 & 0.796 \\
\hline \multicolumn{8}{|l|}{ AIV. Smaller Farms in $97=1$} \\
\hline Draft Animals Ownership & 3206 & 41.08 & 0.492 & 1748 & 39.59 & 0.489 & 0.452 \\
\hline Production Animals Ownership & 3206 & 85.90 & 0.348 & 1748 & 88.39 & 0.320 & -1.288 \\
\hline Number Draft Animals $\dagger$ & 1313 & 0.97 & 1.604 & 691 & 0.89 & 1.484 & 0.689 \\
\hline Number Production Animals $\dagger$ & 2752 & 1.20 & 1.976 & 1541 & 1.18 & 2.086 & 0.168 \\
\hline Number Hectares Used $\dagger$ & 3206 & 1.60 & 0.749 & 1748 & 1.66 & 0.749 & -1.472 \\
\hline \multicolumn{8}{|l|}{ AV. Bigger Farms in $97=1$} \\
\hline Draft Animals Ownership & 851 & 61.46 & 0.487 & 621 & 56.52 & 0.496 & 1.191 \\
\hline Production Animals Ownership & 851 & 91.89 & 0.273 & 621 & 94.36 & 0.231 & -1.602 \\
\hline Number Draft Animals $\dagger$ & 522 & 1.22 & 1.998 & 351 & 1.16 & 1.562 & 0.330 \\
\hline Number Production Animals $\dagger$ & 780 & 2.68 & 3.760 & 585 & 2.41 & 3.579 & 0.851 \\
\hline Number Hectares Used $\dagger$ & 851 & 6.74 & 3.654 & 621 & 6.53 & 3.454 & 0.664 \\
\hline \multicolumn{8}{|c|}{ B. Average Treatment Effect -Dependent Variables Oct 98 to Nov 99} \\
\hline BI. Entire Sub-Sample & & & & & & & \\
\hline Draft Animals Ownership $=1$ & 19406 & 29.19 & 0.455 & 11805 & 24.88 & 0.432 & $2.013^{*}$ \\
\hline Production Animals Ownership $=1$ & 19406 & 74.81 & 0.434 & 11805 & 70.99 & 0.454 & $2.115^{*}$ \\
\hline Land Use $=1$ & 19409 & 61.62 & 0.486 & 11805 & 59.06 & 0.492 & 0.998 \\
\hline Number of Draft Animals $\dagger$ & 5641 & 0.66 & 1.070 & 2928 & 0.62 & 0.994 & 0.658 \\
\hline Number of Production Animals $\dagger$ & 14490 & 1.02 & 1.951 & 8357 & 0.90 & 1.829 & 1.437 \\
\hline Number of Hectares Used $\dagger$ & 11886 & 2.10 & 2.182 & 6928 & 2.10 & 2.171 & -0.009 \\
\hline Household has a Micro-Enterprise $=1$ & 19409 & 8.48 & 0.279 & 11805 & 5.85 & 0.235 & $1.855+$ \\
\hline Household has a Female Micro-Enterprise $=1$ & 19409 & 8.11 & 0.273 & 11805 & 5.13 & 0.221 & $2.217^{*}$ \\
\hline BII. No Agricultural Assets Households in 9 & & & & & & & \\
\hline Draft Animals Ownership $=1$ & 1814 & 7.55 & 0.264 & 1212 & 9.16 & 0.289 & -0.937 \\
\hline Production Animals Ownership =1 & 1814 & 50.88 & 0.500 & 1212 & 42.16 & 0.494 & $2.862^{\star \star}$ \\
\hline Land Use $=1$ & 1816 & 27.75 & 0.448 & 1212 & 22.03 & 0.415 & $1.719+$ \\
\hline Number of Draft Animals $†$ & 137 & 0.41 & 0.580 & 110 & 0.34 & 0.266 & 1.008 \\
\hline Number of Production Animals $\dagger$ & 921 & 0.41 & 0.901 & 510 & 0.37 & 0.803 & 0.453 \\
\hline Number of Hectares Used $\dagger$ & 503 & 1.25 & 1.403 & 264 & 1.36 & 1.369 & -0.854 \\
\hline Household has a Micro-Enterprise $=1$ & 1816 & 7.21 & 0.259 & 1212 & 4.37 & 0.205 & 1.203 \\
\hline Household has a Female Micro-Enterprise $=1$ & 1816 & 6.77 & 0.251 & 1212 & 3.63 & 0.187 & 1.395 \\
\hline BIII. Landless Households in $97=1$ & & & & & & & \\
\hline Draft Animals Ownership $=1$ & 5908 & 24.68 & 0.431 & 3768 & 19.03 & 0.393 & $2.438^{\star \star}$ \\
\hline Production Animals Ownership $=1$ & 5908 & 75.00 & 0.433 & 3768 & 72.03 & 0.449 & 1.496 \\
\hline Land Use $=1$ & 5908 & 41.22 & 0.492 & 3768 & 36.73 & 0.482 & $1.683+$ \\
\hline Number of Draft Animals $†$ & 1451 & 0.49 & 0.888 & 714 & 0.44 & 0.606 & 1.166 \\
\hline Number of Production Animals $\dagger$ & 4426 & 0.77 & 1.454 & 2706 & 0.64 & 1.316 & $1.767+$ \\
\hline Number of Hectares Used $\dagger$ & 2425 & 1.61 & 1.860 & 1379 & 1.55 & 1.580 & 0.653 \\
\hline Household has a Micro-Enterprise =1 & 5908 & 8.26 & 0.275 & 3768 & 5.52 & 0.228 & $1.761+$ \\
\hline Household has a Female Micro-Enterprise $=1$ & 5908 & 7.97 & 0.271 & 3768 & 4.99 & 0.218 & $1.949 *$ \\
\hline BIV. $\underline{\text { Smaller Farms in } 97=1}$ & & & & & & & \\
\hline Draft Animals Ownership $=1$ & 9171 & 31.21 & 0.463 & 5004 & 27.26 & 0.445 & 1.369 \\
\hline Production Animals Ownership $=1$ & 9171 & 76.91 & 0.421 & 5004 & 73.90 & 0.439 & 1.343 \\
\hline Land Use $=1$ & 9172 & 75.44 & 0.430 & 5004 & 76.08 & 0.427 & -0.321 \\
\hline Number of Draft Animalst & 2847 & 0.68 & 1.126 & 1359 & 0.58 & 0.792 & $1.669+$ \\
\hline Number of Production Animals $\dagger$ & 7046 & 1.03 & 1.847 & 3688 & 0.87 & 1.660 & $1.666+$ \\
\hline Number of Hectares Used & 6887 & 1.90 & 1.903 & 3798 & 1.81 & 1.595 & 1.121 \\
\hline Household has a Micro-Enterprise $=1$ & 9172 & 8.93 & 0.285 & 5004 & 6.10 & 0.239 & 1.579 \\
\hline Household has a Female Micro-Enterprise $=1$ & 9172 & 8.50 & 0.279 & 5004 & 5.14 & 0.221 & $1.996^{*}$ \\
\hline BV. Bigger Farms in $97=1$ & & & & & & & \\
\hline Draft Animals Ownership $=1$ & 2451 & 48.51 & 0.500 & 1784 & 40.81 & 0.492 & $1.994^{*}$ \\
\hline Production Animals Ownership $=1$ & 2451 & 83.92 & 0.367 & 1784 & 79.88 & 0.401 & $1.804+$ \\
\hline Land Use $=1$ & 2451 & 83.80 & 0.369 & 1784 & 83.02 & 0.376 & 0.379 \\
\hline Number of Draft Animals $\dagger$ & 1187 & 0.83 & 1.103 & 728 & 0.87 & 1.351 & -0.307 \\
\hline Number of Production Animals $\dagger$ & 2043 & 1.77 & 2.953 & 1423 & 1.62 & 2.770 & 0.690 \\
\hline Number of Hectares Used & 2027 & 3.56 & 2.832 & 1460 & 3.50 & 3.178 & 0.213 \\
\hline Household has a Micro-Enterprise $=1$ & 2451 & 8.08 & 0.273 & 1784 & 7.01 & 0.255 & 0.891 \\
\hline Household has a Female Micro-Enterprise $=1$ & 2451 & 7.79 & 0.268 & 1784 & 6.56 & 0.248 & 1.041 \\
\hline
\end{tabular}

Notes: +significant at $10 \%$, *significant at $5 \%$, **significant at $1 \%$. T-stat of differences in means computed clustering SE at the community level. Mean of dichotomous variables

expressed in percentages. Smaller farms are landed households using, at least, $3 \mathrm{Ha}$. of land; bigger farms use more than $3 \mathrm{Ha}$. Number of draft or production animals are expressed in equivalent cow units. †Continuous variables conditional on being positive. 
Table 5: Effect of OPORTUNIDADES on Agricultural Investments -Treatment and Control Variation Sub-sample of Original Poor Households in October 1998, May 1999 and November 1999 -Intent to Treat (ITT) and Actual Treatments (TOT)

\begin{tabular}{|c|c|c|c|c|c|c|}
\hline PANEL I: DICHOTOMOUS OUTCOMES & $\begin{array}{c}\text { Draft Animal } \\
\text { Ownership } \\
\text { (PROBIT) }\end{array}$ & $\begin{array}{l}\text { Draft Animal } \\
\text { Ownership } \\
\left.\text { p(yly }\left.\right|_{97}=0\right) \\
\text { (PROBIT) }\end{array}$ & $\begin{array}{c}\text { Production } \\
\text { Animal } \\
\text { Ownership } \\
\text { (PROBIT) }\end{array}$ & $\begin{array}{c}\text { Production Animal } \\
\text { Ownership } \\
\mathrm{p}\left(\mathrm{y} \mid \mathrm{y}_{97}=0\right) \\
\text { (PROBIT) }\end{array}$ & $\begin{array}{l}\text { Land Use } \\
\text { (PROBIT) }\end{array}$ & $\begin{array}{l}\text { Land Use } \\
\left.\text { p(yly } y_{97}=0\right) \\
\text { (PROBIT) }\end{array}$ \\
\hline \multicolumn{7}{|l|}{ Model A: ITT -no controls } \\
\hline Treatment Status & $\begin{array}{l}0.043^{\star} \\
(0.021)\end{array}$ & $\begin{array}{l}0.025+ \\
(0.013)\end{array}$ & $\begin{array}{l}0.038^{*} \\
(0.018)\end{array}$ & $\begin{array}{l}0.065^{\star} \\
(0.027)\end{array}$ & $\begin{array}{c}0.029 \\
(0.025)\end{array}$ & $\begin{array}{l}0.053^{*} \\
(0.026)\end{array}$ \\
\hline \multicolumn{7}{|l|}{ Model B: TOT -no controls } \\
\hline Treatment Status & $\begin{array}{l}0.043^{\star} \\
(0.021)\end{array}$ & $\begin{array}{l}0.024+ \\
(0.013)\end{array}$ & $\begin{array}{l}0.039^{\star} \\
(0.018)\end{array}$ & $\begin{array}{l}0.062^{\star} \\
(0.029)\end{array}$ & $\begin{array}{c}0.026 \\
(0.026)\end{array}$ & $\begin{array}{l}0.050+ \\
(0.027)\end{array}$ \\
\hline \multicolumn{7}{|l|}{ Model C: ITT -controls } \\
\hline Treatment Status & $\begin{array}{l}0.046^{\star *} \\
(0.018)\end{array}$ & $\begin{array}{l}0.023^{*} \\
(0.011)\end{array}$ & $\begin{array}{l}0.037^{\star} \\
(0.016)\end{array}$ & $\begin{array}{l}0.061^{*} \\
(0.027)\end{array}$ & $\begin{array}{c}0.028 \\
(0.025)\end{array}$ & $\begin{array}{l}0.053^{*} \\
(0.025)\end{array}$ \\
\hline \multicolumn{7}{|l|}{ Model D: TOT -controls } \\
\hline Treatment Status & $\begin{array}{l}0.044^{\star} \\
(0.017)\end{array}$ & $\begin{array}{l}0.022^{\star} \\
(0.011)\end{array}$ & $\begin{array}{l}0.037^{\star} \\
(0.017)\end{array}$ & $\begin{array}{l}0.062^{\star} \\
(0.028)\end{array}$ & $\begin{array}{c}0.028 \\
(0.025)\end{array}$ & $\begin{array}{l}0.052^{\star} \\
(0.025)\end{array}$ \\
\hline \multicolumn{7}{|l|}{ Model E: TOT by Farm Size at Baseline (1997) -controls } \\
\hline Treatment Status * No Agricultural Assets & $\begin{array}{l}-0.009 \\
(0.034)\end{array}$ & $\begin{array}{l}-0.008 \\
(0.019)\end{array}$ & $\begin{array}{l}0.075^{\star \star} \\
(0.022)\end{array}$ & $\begin{array}{l}0.094^{\star *} \\
(0.033)\end{array}$ & $\begin{array}{l}0.063+ \\
(0.038)\end{array}$ & $\begin{array}{l}0.065+ \\
(0.039)\end{array}$ \\
\hline Treatment Status * Landless & $\begin{array}{l}0.065^{\star} \\
(0.026)\end{array}$ & $\begin{array}{l}0.035^{\star} \\
(0.017)\end{array}$ & $\begin{array}{l}0.029+ \\
(0.018)\end{array}$ & $\begin{array}{c}0.096 \\
(0.075)\end{array}$ & $\begin{array}{l}0.045+ \\
(0.025)\end{array}$ & $\begin{array}{l}0.049+ \\
(0.025)\end{array}$ \\
\hline Treatment Status * Smaller Farm & $\begin{array}{l}0.038+ \\
(0.022)\end{array}$ & $\begin{array}{l}0.029+ \\
(0.016)\end{array}$ & $\begin{array}{c}0.028 \\
(0.020)\end{array}$ & $\begin{array}{l}-0.003 \\
(0.041)\end{array}$ & $\begin{array}{l}-0.002 \\
(0.025)\end{array}$ & - \\
\hline Treatment Status * Bigger Farm & $\begin{array}{c}0.046 \\
(0.028)\end{array}$ & $\begin{array}{c}0.000 \\
(0.022)\end{array}$ & $\begin{array}{c}0.035 \\
(0.023)\end{array}$ & $\begin{array}{c}0.007 \\
(0.083)\end{array}$ & $\begin{array}{c}0.026 \\
(0.032)\end{array}$ & - \\
\hline Observations ITT Sub-Sample (Model A and C) & 33313 & 21899 & 33313 & 5964 & 33316 & 13641 \\
\hline Mean Dependent Variable ITT Sub-Sample (All) & 0.275 & 0.124 & 0.729 & 0.494 & 0.605 & 0.360 \\
\hline Mean Dependent Variable ITT Sub-Sample (Controls) & 0.248 & 0.108 & 0.706 & 0.453 & 0.588 & 0.329 \\
\hline Observations TOT Sub-Sample (Models B, D, E) & 31211 & 20477 & 31211 & 5457 & 31214 & 12708 \\
\hline Mean Dependent Variable TOT Sub-Sample (All) & 0.276 & 0.123 & 0.734 & 0.500 & 0.606 & 0.361 \\
\hline Mean Dependent Variable TOT Sub-Sample (Controls) & 0.248 & 0.109 & 0.710 & 0.461 & 0.591 & 0.332 \\
\hline PANEL II: CONTINUOUS OUTCOMES & $\begin{array}{c}\text { Number of } \\
\text { Equivalent } \\
\text { Draft Animals } \\
\text { (LS) } \\
\end{array}$ & $\begin{array}{c}\text { Number of } \\
\text { Equivalent } \\
\text { Draft Animals } \\
\left.\text { p(yly } y_{97}>0\right) \\
(\text { LS }) \\
\end{array}$ & $\begin{array}{c}\text { Number of } \\
\text { Equivalent } \\
\text { Production } \\
\text { Animals } \\
\text { (LS) } \\
\end{array}$ & $\begin{array}{c}\text { Number of } \\
\text { Equivalent } \\
\text { Production Animals } \\
\mathrm{p}\left(\mathrm{y} \mid \mathrm{y}_{97}>0\right) \\
(\mathrm{LS}) \\
\end{array}$ & $\begin{array}{c}\text { Number of } \\
\text { Hectares } \\
\text { Used } \\
\text { (LS) }\end{array}$ & $\begin{array}{c}\text { Number of } \\
\text { Hectares Used } \\
\left.\text { p(y|y } y_{97}>0\right) \\
(L S)\end{array}$ \\
\hline \multicolumn{7}{|l|}{ Model A: ITT -no controls } \\
\hline Treatment Status & $\begin{array}{c}0.030 \\
(0.025)\end{array}$ & $\begin{array}{c}0.056 \\
(0.035)\end{array}$ & $\begin{array}{c}0.086 \\
(0.075)\end{array}$ & $\begin{array}{c}0.103 \\
(0.080)\end{array}$ & $\begin{array}{c}0.031 \\
(0.089)\end{array}$ & $\begin{array}{c}0.008 \\
(0.115)\end{array}$ \\
\hline \multicolumn{7}{|l|}{ Model B: TOT -no controls } \\
\hline Treatment Status & $\begin{array}{c}0.029 \\
(0.025)\end{array}$ & $\begin{array}{c}0.058 \\
(0.037)\end{array}$ & $\begin{array}{c}0.090 \\
(0.072)\end{array}$ & $\begin{array}{c}0.103 \\
(0.076)\end{array}$ & $\begin{array}{c}0.036 \\
(0.091)\end{array}$ & $\begin{array}{c}0.023 \\
(0.117)\end{array}$ \\
\hline \multicolumn{7}{|l|}{ Model C: ITT -controls } \\
\hline Treatment Status & $\begin{array}{c}0.030 \\
(0.022)\end{array}$ & $\begin{array}{l}0.060+ \\
(0.033)\end{array}$ & $\begin{array}{c}0.084 \\
(0.067)\end{array}$ & $\begin{array}{c}0.099 \\
(0.071)\end{array}$ & $\begin{array}{c}0.026 \\
(0.084)\end{array}$ & $\begin{array}{c}0.014 \\
(0.112)\end{array}$ \\
\hline \multicolumn{7}{|l|}{ Model D: TOT -controls } \\
\hline Treatment Status & $\begin{array}{c}0.031 \\
(0.023)\end{array}$ & $\begin{array}{l}0.062+ \\
(0.034)\end{array}$ & $\begin{array}{c}0.092 \\
(0.065)\end{array}$ & $\begin{array}{c}0.100 \\
(0.068)\end{array}$ & $\begin{array}{c}0.038 \\
(0.086)\end{array}$ & $\begin{array}{c}0.031 \\
(0.113)\end{array}$ \\
\hline \multicolumn{7}{|l|}{ Model E: TOT by Farm Size at Baseline (1997) -controls } \\
\hline Treatment Status * No Agricultural Assets & $\begin{array}{c}0.005 \\
(0.030)\end{array}$ & - & $\begin{array}{c}0.022 \\
(0.082)\end{array}$ & - & $\begin{array}{c}0.047 \\
(0.090)\end{array}$ & - \\
\hline Treatment Status * Landless & $\begin{array}{c}0.019 \\
(0.024)\end{array}$ & $\begin{array}{c}0.017 \\
(0.047)\end{array}$ & $\begin{array}{c}0.012 \\
(0.066)\end{array}$ & $\begin{array}{c}0.007 \\
(0.070)\end{array}$ & $\begin{array}{c}0.060 \\
(0.070)\end{array}$ & - \\
\hline Treatment Status * Smaller Farm & $\begin{array}{l}0.071^{\star \star} \\
(0.023)\end{array}$ & $\begin{array}{l}0.078^{\star} \\
(0.038)\end{array}$ & $\begin{array}{l}0.119+ \\
(0.064)\end{array}$ & $\begin{array}{l}0.125+ \\
(0.069)\end{array}$ & $\begin{array}{c}0.036 \\
(0.068)\end{array}$ & $\begin{array}{c}0.055 \\
(0.097)\end{array}$ \\
\hline Treatment Status * Bigger Farm & $\begin{array}{l}0.088^{\star \star} \\
(0.028)\end{array}$ & $\begin{array}{l}0.112^{\star} \\
(0.046)\end{array}$ & $\begin{array}{l}0.234^{\star *} \\
(0.076)\end{array}$ & $\begin{array}{l}0.291^{\text {** }} \\
(0.083)\end{array}$ & $\begin{array}{l}0.162^{*} \\
(0.082)\end{array}$ & $\begin{array}{c}0.182 \\
(0.111)\end{array}$ \\
\hline Observations ITT Sub-Sample (Model A and C) & 33313 & 11385 & 33313 & 27301 & 33193 & 19573 \\
\hline Mean Dependent Variable ITT Sub-Sample (All) & 0.176 & 0.403 & 0.722 & 0.825 & 1.265 & 1.763 \\
\hline Mean Dependent Variable ITT Sub-Sample (Controls) & 0.152 & 0.367 & 0.651 & 0.741 & 1.239 & 1.790 \\
\hline Observations TOT Sub-Sample (Models B, D, E) & 31211 & 10707 & 31211 & 25708 & 31097 & 18406 \\
\hline Mean Dependent Variable TOT Sub-Sample (All) & 0.152 & 0.367 & 0.639 & 0.725 & 1.240 & 1.780 \\
\hline Mean Dependent Variable TOT Sub-Sample (Controls) & 0.176 & 0.403 & 0.715 & 0.815 & 1.273 & 1.767 \\
\hline
\end{tabular}


Table 6: Effect of OPORTUNIDADES on Micro-Entepreneurial Investments -Treatment and Control Variation. Sub-sample of Original Poor Households in October 1998, May 1999 and November 1999 -Intent to Treat (ITT) and Actual Treatments (TOT)

\begin{tabular}{lcc}
\hline \hline & $\begin{array}{c}\text { Female } \\
\text { Model A: ITT -no controls }\end{array}$ & $\begin{array}{c}\text { Micro-Enterprise } \\
\text { (PROBIT) }\end{array}$ \\
\hline Treatment Status & $0.026+$ & $0.030^{\star}$ \\
(PROBIT) & $(0.013)$ \\
Model B: TOT -no controls & $(0.014)$ & $0.028^{\star}$ \\
\hline Treatment Status & $0.025+$ & $(0.013)$ \\
Model C: ITT -controls & $(0.014)$ & $0.031^{\star *}$ \\
\hline Treatment Status & & $(0.012)$ \\
Model D: TOT -controls & $0.029^{\star}$ & $0.030^{\star *}$ \\
\hline Treatment Status & $(0.012)$ & $(0.011)$ \\
\hline Observations ITT Sub-Sample (Model A and C) & $0.028^{\star}$ & 33316 \\
Mean Dependent Variable ITT Sub-Sample (All) & $(0.012)$ & 0.071 \\
Mean Dependent Variable ITT Sub-Sample (Controls) & 33316 & 0.051 \\
\hline Observations TOT Sub-Sample (Models B and D) & 0.076 & 31214 \\
Mean Dependent Variable TOT Sub-Sample (All) & 0.058 & 0.070 \\
Mean Dependent Variable TOT Sub-Sample (Controls) & 31214 & 0.051 \\
\hline \hline
\end{tabular}

Notes: +significant at 10\%, *significant at 5\%, ${ }^{* *}$ significant at $1 \%$. SE in parentheses. Marginal effects and robust standard errors reported, clustered at the community level. All regressions include wave dummies. Controls in models C and D include head's and spouse's age, age squared and education level dummies, head's ethnicity (language), household size, dummies controlling for household demographics, baseline assets (home ownership, dirt floor and electricity) and community characteristics (community organizations, distance to urban center and wages). 
Table 7: Effect of OPORTUNIDADES on Agricultural Investments by Quintiles of Cumulative Transfer (Potential and Actual) Sub-sample of Original Poor Households from October 1998 through November 2003 -Treatment on the Treated (TOT)

\begin{tabular}{|c|c|c|c|c|c|c|c|}
\hline & Quintile 1 & Quintile 2 & Quintile 3 & Quintile 4 & Quintile 5 & $\begin{array}{l}\text { Number } \\
\text { of Obs. }\end{array}$ & $\begin{array}{c}\text { Mean } \\
\text { Dep. Var. }\end{array}$ \\
\hline \multicolumn{8}{|l|}{ I. DRAFT ANIMALS OWNERSHIP (PROBIT) } \\
\hline $\begin{array}{l}\text { Model A TOT -Controls, Potential Transfer } \\
\text { Treatment Status * Quintile }\end{array}$ & $\begin{array}{c}0.023 \\
(0.015)\end{array}$ & $\begin{array}{l}0.035+ \\
(0.020)\end{array}$ & $\begin{array}{l}0.041+ \\
(0.022)\end{array}$ & $\begin{array}{l}0.057^{*} \\
(0.028)\end{array}$ & $\begin{array}{l}0.066+ \\
(0.034)\end{array}$ & 51327 & 0.286 \\
\hline \multicolumn{8}{|l|}{ Model B: TOT -Controls, Actual Transfer } \\
\hline Treatment Status * Quintile & $\begin{array}{c}0.014 \\
(0.015)\end{array}$ & $\begin{array}{c}0.044^{*} \\
(0.020)\end{array}$ & $\begin{array}{l}0.045^{\star} \\
(0.023)\end{array}$ & $\begin{array}{l}0.055^{\star} \\
(0.027)\end{array}$ & $\begin{array}{l}0.076^{*} \\
(0.034)\end{array}$ & 51327 & 0.286 \\
\hline \multicolumn{8}{|l|}{ Model C: TOT -Controls, Actual Transfer $p\left(y \mid y_{97}=0\right)$} \\
\hline Treatment Status * Quintile & $\begin{array}{c}0.008 \\
(0.010)\end{array}$ & $\begin{array}{c}0.019 \\
(0.014)\end{array}$ & $\begin{array}{c}0.026 \\
(0.017)\end{array}$ & $\begin{array}{l}0.036+ \\
(0.020)\end{array}$ & $\begin{array}{l}0.058^{\star} \\
(0.027)\end{array}$ & 33649 & 0.136 \\
\hline \multicolumn{8}{|c|}{ Model D: TOT by Farm Size in 97 -Controls, Actual Transfer $p\left(y \mid y{ }_{9 z}=0\right)$} \\
\hline Treatment Status * Quintile * No Agricultural Assets & $\begin{array}{l}-0.008 \\
(0.016)\end{array}$ & $\begin{array}{l}-0.011 \\
(0.021)\end{array}$ & $\begin{array}{l}-0.005 \\
(0.028)\end{array}$ & $\begin{array}{c}0.019 \\
(0.029)\end{array}$ & $\begin{array}{c}0.053 \\
(0.035)\end{array}$ & 33649 & 0.136 \\
\hline Treatment Status * Quintile * Landless & $\begin{array}{c}0.020 \\
(0.014)\end{array}$ & $\begin{array}{l}0.031+ \\
(0.019)\end{array}$ & $\begin{array}{l}0.051^{*} \\
(0.024)\end{array}$ & $\begin{array}{l}0.055^{\star} \\
(0.025)\end{array}$ & $\begin{array}{l}0.062+ \\
(0.033)\end{array}$ & & \\
\hline Treatment Status * Quintile * Smaller Farm & $\begin{array}{c}0.010 \\
(0.014)\end{array}$ & $\begin{array}{c}0.028 \\
(0.018)\end{array}$ & $\begin{array}{c}0.024 \\
(0.020)\end{array}$ & $\begin{array}{l}0.038+ \\
(0.023)\end{array}$ & $\begin{array}{l}0.064^{*} \\
(0.031)\end{array}$ & & \\
\hline Treatment Status * Quintile * Bigger Farm & $\begin{array}{l}-0.002 \\
(0.018)\end{array}$ & $\begin{array}{l}-0.008 \\
(0.024)\end{array}$ & $\begin{array}{c}0.000 \\
(0.026)\end{array}$ & $\begin{array}{c}0.005 \\
(0.027)\end{array}$ & $\begin{array}{c}0.050 \\
(0.035)\end{array}$ & & \\
\hline \multicolumn{8}{|l|}{ II. PRODUCTION ANIMALS OWNERSHIP (PROBIT) } \\
\hline \multicolumn{8}{|l|}{ Model A: TOT-Controls, Potential Transfer } \\
\hline$\overline{\text { Treatment Status * Quintile }}$ & $\begin{array}{l}-0.015 \\
(0.013)\end{array}$ & $\begin{array}{c}0.015 \\
(0.016)\end{array}$ & $\begin{array}{l}0.030+ \\
(0.017)\end{array}$ & $\begin{array}{l}0.057^{\star *} \\
(0.021)\end{array}$ & $\begin{array}{l}0.065^{\star *} \\
(0.023)\end{array}$ & 51333 & 0.741 \\
\hline \multicolumn{8}{|l|}{ Model B: TOT -Controls, Actual Transfer } \\
\hline $\begin{array}{l}\text { Treatment Status * Quintile } \\
\end{array}$ & $\begin{array}{l}-0.016 \\
(0.013)\end{array}$ & $\begin{array}{c}0.019 \\
(0.016)\end{array}$ & $\begin{array}{c}0.027 \\
(0.019)\end{array}$ & $\begin{array}{l}0.054^{\star *} \\
(0.021)\end{array}$ & $\begin{array}{l}0.079 * * \\
(0.023)\end{array}$ & 51333 & 0.741 \\
\hline \multicolumn{8}{|l|}{ Model C: TOT -Controls, Actual Transfer $p\left(y y_{97}=0\right)$} \\
\hline Treatment Status * Quintile & $\begin{array}{c}0.018 \\
(0.024)\end{array}$ & $\begin{array}{l}0.057^{*} \\
(0.029)\end{array}$ & $\begin{array}{c}0.062 \\
(0.038)\end{array}$ & $\begin{array}{l}0.111^{*} \\
(0.048)\end{array}$ & $\begin{array}{l}0.166^{* *} \\
(0.057)\end{array}$ & 8924 & 0.524 \\
\hline \multicolumn{8}{|c|}{ Model D: TOT by Farm Size in 97 -Controls, Actual Transfer $p\left(y \mid y{ }_{9 z}=0\right)$} \\
\hline Treatment Status * Quintile * No Agricultural Assets & $\begin{array}{c}0.037 \\
(0.026)\end{array}$ & $\begin{array}{l}0.098^{\star *} \\
(0.034)\end{array}$ & $\begin{array}{l}0.070+ \\
(0.041)\end{array}$ & $\begin{array}{l}0.163^{* *} \\
(0.045)\end{array}$ & $\begin{array}{l}0.197^{\star *} \\
(0.051)\end{array}$ & 8924 & 0.524 \\
\hline Treatment Status * Quintile * Landless & $\begin{array}{l}-0.051 \\
(0.077)\end{array}$ & $\begin{array}{c}0.004 \\
(0.079)\end{array}$ & $\begin{array}{c}0.048 \\
(0.104)\end{array}$ & $\begin{array}{c}0.127 \\
(0.088)\end{array}$ & $\begin{array}{c}0.085 \\
(0.121)\end{array}$ & & \\
\hline Treatment Status * Quintile * Smaller Farm & $\begin{array}{c}-0.011 \\
(0.036)\end{array}$ & $\begin{array}{c}0.002 \\
(0.041)\end{array}$ & $\begin{array}{c}0.022 \\
(0.052)\end{array}$ & $\begin{array}{c}0.021 \\
(0.062)\end{array}$ & $\begin{array}{c}0.131^{*} \\
(0.063)\end{array}$ & & \\
\hline Treatment Status * Quintile * Bigger Farm & $\begin{array}{l}-0.010 \\
(0.078)\end{array}$ & $\begin{array}{l}-0.059 \\
(0.082)\end{array}$ & $\begin{array}{c}0.119 \\
(0.094)\end{array}$ & $\begin{array}{c}0.071 \\
(0.097)\end{array}$ & $\begin{array}{c}0.139 \\
(0.118)\end{array}$ & & \\
\hline \multicolumn{8}{|l|}{ III. LAND USE (PROBIT) } \\
\hline \multicolumn{8}{|l|}{ Model A: TOT -Controls, Potential Transfer } \\
\hline$\overline{\text { Treatment Status * Quintile }}$ & $\begin{array}{c}0.006 \\
(0.020)\end{array}$ & $\begin{array}{c}0.023 \\
(0.025)\end{array}$ & $\begin{array}{c}0.024 \\
(0.027)\end{array}$ & $\begin{array}{c}0.033 \\
(0.031)\end{array}$ & $\begin{array}{c}0.040 \\
(0.035)\end{array}$ & 51390 & 0.619 \\
\hline \multicolumn{8}{|l|}{ Model B: TOT -Controls, Actual Transfer } \\
\hline Treatment Status * Quintile & $\begin{array}{c}0.009 \\
(0.020)\end{array}$ & $\begin{array}{c}0.015 \\
(0.025)\end{array}$ & $\begin{array}{c}0.027 \\
(0.028)\end{array}$ & $\begin{array}{c}0.039 \\
(0.030)\end{array}$ & $\begin{array}{l}0.062+ \\
(0.033)\end{array}$ & 51390 & 0.619 \\
\hline \multicolumn{8}{|l|}{ Model C: TOT -Controls, Actual Transfer $p\left(y \mid y_{97}=0\right)$} \\
\hline Treatment Status * Quintile & $\begin{array}{c}0.033 \\
(0.021)\end{array}$ & $\begin{array}{c}0.045 \\
(0.028)\end{array}$ & $\begin{array}{c}0.064+ \\
(0.033)\end{array}$ & $\begin{array}{l}0.064+ \\
(0.036)\end{array}$ & $\begin{array}{c}0.098^{*} \\
(0.044)\end{array}$ & 20868 & 0.387 \\
\hline \multicolumn{8}{|c|}{ Model D: TOT by Farm Size in 97 -Controls, Actual Transfer $p\left(y \mid y{ }_{9 z}=0\right)$} \\
\hline Treatment Status * Quintile * No Agricultural Assets & $\begin{array}{c}0.049 \\
(0.032)\end{array}$ & $\begin{array}{c}0.058 \\
(0.040)\end{array}$ & $\begin{array}{c}0.093^{\star} \\
(0.046)\end{array}$ & $\begin{array}{c}0.043 \\
(0.046)\end{array}$ & $\begin{array}{l}0.116^{*} \\
(0.054)\end{array}$ & 20868 & 0.387 \\
\hline Treatment Status * Quintile * Landless & $\begin{array}{c}0.031 \\
(0.022)\end{array}$ & $\begin{array}{c}0.041 \\
(0.028)\end{array}$ & $\begin{array}{l}0.056+ \\
(0.034)\end{array}$ & $\begin{array}{l}0.065+ \\
(0.036)\end{array}$ & $\begin{array}{c}0.090 * \\
(0.044)\end{array}$ & & \\
\hline Treatment Status * Quintile * Smaller Farm & - & - & - & - & - & & \\
\hline Treatment Status * Quintile * Bigger Farm & - & $\begin{array}{l}- \\
-\end{array}$ & $\begin{array}{l}- \\
-\end{array}$ & - & - & & \\
\hline
\end{tabular}


Number Mean Quintile 1 Quintile 2 Quintile 3 Quintile 4 Quintile 5 of Obs. Dep. Var.

IV. NUMBER OF EQUIVALENT DRAFT ANIMALS (LS)

\section{Model A: TOT -Controls, Potential Transfer}

Treatment Status * Quintile

Model B: TOT -Controls, Actual Transfer

Treatment Status * Quintile

Model C: TOT -Controls, Actual Transfer $p\left(y \mathrm{l}_{97}>0\right)$

Treatment Status * Quintile

Model D: TOT by Farm Size in 97 -Controls, Actual Transfer $p\left(y \mid y_{97}>0\right)$

Treatment Status * Quintile * No Agricultural Assets

Treatment Status * Quintile * Landless

Treatment Status * Quintile * Smaller Farm

Treatment Status * Quintile * Bigger Farm

\section{NUMBER OF EQUIVALENT PRODUCTION ANIMALS (LS)}

\section{Model A: TOT -Controls, Potential Transfer}

Treatment Status * Quintile

Model B: TOT -Controls, Actual Transfer

Treatment Status * Quintile

Model C: TOT -Controls, Actual Transfer p(yly $\left.{ }_{9 z}>0\right)$

Treatment Status * Quintile

Model D: TOT by Farm Size in 97 -Controls, Actual Transfer p(yly $\left.{ }_{9 z} \geq 0\right)$

Treatment Status * Quintile * No Agricultural Assets

Treatment Status * Quintile * Landless

Treatment Status * Quintile * Smaller Farm

Treatment Status * Quintile * Bigger Farm

\section{NUMBER OF HECTARES (LS)}

\section{Model A: TOT -Controls, Potential Transfer}

Treatment Status * Quintile

Model B: TOT -Controls, Actual Transfer

Treatment Status * Quintile

Model C: TOT -Controls, Actual Transfer $\left.p(y \mid y)_{9 z}>0\right)$

Treatment Status * Quintile

Model D: TOT by Farm Size in 97 -Controls, Actual Transfer $p\left(y y_{9 z}>0\right)$

Treatment Status * Quintile * No Agricultural Assets

Treatment Status * Quintile * Landless

Treatment Status * Quintile * Smaller Farm

Treatment Status * Quintile * Bigger Farm
0.008

$(0.015)$

0.007

(0.015)

0.019

$(0.032)$

(0.035)

0.007

0.019

0.003

-

0.002

(0.059)

0.012

(0.041)

0.040

(0.058)
(0.017)

(0.017)

(0.035)

0.003

(0.019)

0.025

(0.020)

0.040

$(0.039)$

-

$0.002 \quad 0.000$

(0.063) (0.068)

$0.013 \quad 0.042$

(0.044) (0.048)

0.037

(0.062)

$(0.048)$
0.085

(0.066)

0.003

$(0.022)$

0.034

0.217

$0.013 \quad 0.058^{*}$

$(0.022) \quad(0.027)$

$51327 \quad 0.217$

$0.048 \quad 0.137$ *

(0.043) (0.055)

$17638 \quad 0.467$

$17638 \quad 0.467$

- $\quad$ -

$\begin{array}{ll}-0.039 & 0.110\end{array}$

(0.068) (0.075)

$0.061 \quad 0.110+$

$(0.050) \quad(0.060)$
0.093

$0.093 \quad 0.175^{*}$

(0.065) (0.071)

$\begin{array}{ccccccc}0.017 & 0.063+ & 0.072^{\star} & 0.147^{\star \star} & 0.164^{\star *} & 51333 & 0.740 \\ (0.028) & (0.033) & (0.036) & (0.043) & (0.053) & & \end{array}$

$51333 \quad 0.740$

$\begin{array}{ccccccc}0.029 & 0.032 & 0.104^{\star *} & 0.181^{\star *} & \begin{array}{l}0.193^{\star *} \\ (0.052)\end{array} & & \\ (0.028) & (0.033) & (0.038) & (0.042) & (0.052) & & 0.740\end{array}$

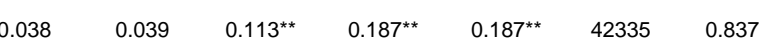

$(0.032) \quad(0.038) \quad(0.043) \quad(0.048) \quad(0.060)$

$42335 \quad 0.837$

$\begin{array}{ccccc}- & - & - & - & - \\ - & - & - & - & - \\ 0.009 & 0.005 & 0.049 & 0.073 & 0.109 \\ (0.047) & (0.053) & (0.059) & (0.061) & (0.070) \\ 0.049 & 0.025 & 0.127^{\star} & 0.196^{\star *} & 0.185^{\star *} \\ (0.043) & (0.048) & (0.052) & (0.056) & (0.065) \\ 0.010 & 0.172^{\star} & 0.237^{\star \star} & 0.410^{\star *} & 0.344^{\star *} \\ (0.070) & (0.076) & (0.080) & (0.078) & (0.084)\end{array}$

Notes: +significant at $10 \%,{ }^{*}$ significant at $5 \%,{ }^{*}$ significant at $1 \%$. SE in parentheses. For the probit models, marginal effects and robust standard errors reported, clustered at the community level. LS regressions include community level random effects. All regressions include wave dummies and controls for head's and spouse's age, age squared and education level dummies, head's ethnicity (language), household size, dummies controlling for household demographics, baseline assets (home ownership, dirt floor and electricity) and community characteristics (community organizations, distance to urban center and wages). Data are for the five waves for which we have data on the dependent variables: October 1998, May 1999, November 1999, May 2000 and November 2003. Smaller farms use up to $3 \mathrm{Ha}$. of land; bigger farms use more than $3 \mathrm{Ha}$. 
Table 8: Consumption and Transfer Amounts -Test of Equality of Means between Actual Treatments and Actual Controls. Sub-Sample of Original Poor from October 1998 to May $1999^{1}$-Treatment on the Treated (TOT)

\begin{tabular}{|c|c|c|c|c|c|c|c|}
\hline \multirow[b]{3}{*}{ I. Entire Sub-Sample } & \multicolumn{3}{|c|}{ Treatment Group } & \multicolumn{3}{|c|}{ Control Group } & \multirow[b]{2}{*}{ t-stat } \\
\hline & $\mathbf{N}$ & Mean & SD & $\mathbf{N}$ & Mean & SD & \\
\hline & & & & & & & \\
\hline Monthly Consumption per Capita (Home Production Included) & 12667 & 194.09 & 96.597 & 7710 & 171.91 & 93.004 & 4.900 \\
\hline Actual Monthly Transfer per Capita & 12667 & 36.35 & 21.528 & - & - & - & - \\
\hline 6-month Lagged Actual Cumulated Transfer per Capita & 12667 & 141.33 & 123.927 & - & - & - & - \\
\hline Potential Monthly Transfer per Capita & 12667 & 48.61 & 26.256 & - & - & - & - \\
\hline 6-month Lagged Potential Cumulated Transfer per Capita & 12667 & 216.64 & 187.569 & - & - & - & - \\
\hline \multicolumn{8}{|l|}{ II. No Agricultural Assets Households in $97=1$} \\
\hline Monthly Consumption per Capita (Home Production Included) & 1187 & 215.02 & 106.803 & 785 & 190.92 & 102.052 & 3.203 \\
\hline \multicolumn{8}{|l|}{ III. Landless Households in $97=1$} \\
\hline Monthly Consumption per Capita (Home Production Included) & 3864 & 199.84 & 95.667 & 2463 & 182.24 & 93.550 & 3.268 \\
\hline \multicolumn{8}{|l|}{ IV. Smaller Farms in $97=1$} \\
\hline Monthly Consumption per Capita (Home Production Included) & 5986 & 187.69 & 94.076 & 3284 & 160.99 & 90.104 & 5.213 \\
\hline \multicolumn{8}{|l|}{ V. Bigger Farms in $97=1$} \\
\hline Monthly Consumption per Capita (Home Production Included) & 1592 & 189.29 & 97.530 & 1154 & 167.67 & 88.754 & 3.046 \\
\hline
\end{tabular}

Table 9: Effect of Current Transfers (Marginal Propensity to Consume) and Lagged Cumulative Transfers on Consumption Sub-sample of Original Poor Households from October 1998 through November $2003^{1}$-Actual Treatments (TOT)

\begin{tabular}{|c|c|c|c|c|}
\hline & $\begin{array}{l}\text { Consumption } \\
\text { Linear I } \\
\text { (LS) }\end{array}$ & $\begin{array}{l}\text { Consumption } \\
\text { Linear II } \\
\text { (LS) }\end{array}$ & $\begin{array}{l}\text { Consumption } \\
\text { Linear III } \\
\text { (2SLS) }\end{array}$ & $\begin{array}{l}\text { Consumption } \\
\text { Linear IV } \\
\text { (2SLS) }\end{array}$ \\
\hline Actual Transfer (monthly pc ae) -Preferences & $\begin{array}{l}0.649^{\star *} \\
(0.020)\end{array}$ & $\begin{array}{l}0.510^{\star *} \\
(0.022)\end{array}$ & $\begin{array}{l}0.733^{\star \star} \\
(0.034)\end{array}$ & $\begin{array}{l}0.884^{\star *} \\
(0.035)\end{array}$ \\
\hline Actual Cumulative Transfer (6 months lag pc ae) -Productivity & & $\begin{array}{l}0.011^{\star \star} \\
(0.001)\end{array}$ & $\begin{array}{l}0.012^{\star *} \\
(0.001)\end{array}$ & $\begin{array}{l}0.018^{\star \star} \\
(0.001)\end{array}$ \\
\hline Full Set of Controls & $\mathrm{N}$ & $\mathrm{N}$ & $\mathrm{N}$ & $\mathrm{Y}$ \\
\hline Number of Observations & 39529 & 39529 & 39529 & 39529 \\
\hline Mean of Dependent Variable (All) & 186.598 & 186.598 & 186.598 & 186.598 \\
\hline Mean of Dependent Variable (Controls) & 176.070 & 176.070 & 176.070 & 176.070 \\
\hline
\end{tabular}

Notes: +significant at 10\%, ${ }^{*}$ significant at $5 \%,{ }^{*}$ significant at 1\%. SE in parentheses. All regressions include random effects at the community level and wave dummies. The full list of controls additionally includes: head's and spouse's age, education level dummies, head's ethnicity (language), household size adult equivalent and household demographic variables, baseline assets (home ownership, dirt floor and electricity), farm size at baseline and community characteristics (community organizations, distance to urban center and wages). The excluded instruments in the 2SLS models are the monthly pc ae potential transfer and the 6 -month lag cumulative potential pc ae transfer. The first stages show significant effects of the excluded instruments on the endogeneous explanatory variables and are available upon request. Consumption is expenditures expressed in per capita adult equivalent units and includes home production. Outliers trimmed at the top and bottom $1 \%$ of both the consumption and transfer distributions. pc means "per capita"; ae means "adult equivalent".

${ }^{1}$ Because of the inclusion of home production, we only have data on consumption for the following rounds: October 1998, May 1999, Nov 2000 and Nov 2003. 
Table 10: Consumption -Heterogeneous Treatment Effects

Sub-sample of Original Poor Households from October 1998 through November $2003^{1}$-Actual Treatments (TOT)

\begin{tabular}{|c|c|c|c|c|c|c|}
\hline \multirow[b]{2}{*}{ Actual Transfer (monthly pc ae) -Preferences } & $\begin{array}{c}\text { Consumption } \\
\text { Linear IV } \\
\text { (2SLS) }\end{array}$ & $\begin{array}{c}\text { Consumption } \\
\text { by Farm Size } \\
\text { (2SLS) }\end{array}$ & $\begin{array}{c}\text { Consumption } \\
\text { by Head's Age } \\
\text { (2SLS) }\end{array}$ & $\begin{array}{c}\text { Consumption } \\
\text { by Head's } \\
\text { Education } \\
\text { (2SLS) }\end{array}$ & $\begin{array}{c}\text { Consumption } \\
\text { by Distance } \\
\text { (2SLS) }\end{array}$ & $\begin{array}{c}\text { Consumption } \\
\text { by Head and } \\
\text { Household } \\
\text { Characteristics }\end{array}$ \\
\hline & & & & & & \\
\hline Linear (Alone) & $\begin{array}{l}0.886^{\star *} \\
(0.035)\end{array}$ & $\begin{array}{l}0.868^{\star *} \\
(0.038)\end{array}$ & $\begin{array}{l}1.094^{\star *} \\
(0.261)\end{array}$ & $\begin{array}{l}1.073^{\star *} \\
(0.055)\end{array}$ & $\begin{array}{l}0.872^{\star \star} \\
(0.034)\end{array}$ & $\begin{array}{l}1.277^{\star \star} \\
(0.288)\end{array}$ \\
\hline Interacted with Non Agricultural Household at Baseline (1997) $=1$ & & $\begin{array}{l}0.181^{*} \\
(0.090)\end{array}$ & & & & $\begin{array}{l}0.166+ \\
(0.091)\end{array}$ \\
\hline Interacted with Bigger Farm at Baseline (1997) $=1$ & & $\begin{array}{c}0.020 \\
(0.078)\end{array}$ & & & & $\begin{array}{l}0.0001 \\
(0.078)\end{array}$ \\
\hline Interacted with Head's Age & & & $\begin{array}{l}-0.017 \\
(0.011)\end{array}$ & & & $\begin{array}{l}-0.018+ \\
(0.011)\end{array}$ \\
\hline Interacted with Head's Age Squared & & & $\begin{array}{l}0.0002^{\star} \\
(0.0001)\end{array}$ & & & $\begin{array}{l}0.0002^{*} \\
(0.0001)\end{array}$ \\
\hline Interacted with Head has not completed primary $=1$ & & & & $\begin{array}{c}-0.251^{\star \star} \\
(0.064)\end{array}$ & & $\begin{array}{l}-0.170^{*} \\
(0.069)\end{array}$ \\
\hline Interacted with Head has completed primary or more $=1$ & & & & $\begin{array}{l}-0.304^{\star *} \\
(0.077)\end{array}$ & & $\begin{array}{l}-0.194^{\star} \\
(0.090)\end{array}$ \\
\hline \multicolumn{7}{|l|}{ Actual Cumulative Transfer (6 months lag pc ae) -Productivity } \\
\hline Linear (Alone) & $\begin{array}{l}0.018^{\star *} \\
(0.001)\end{array}$ & $\begin{array}{l}0.018^{\star \star} \\
(0.001)\end{array}$ & $\begin{array}{l}0.009^{*} \\
(0.004)\end{array}$ & $\begin{array}{l}0.016^{\star \star} \\
(0.001)\end{array}$ & $\begin{array}{l}0.028^{\star \star} \\
(0.002)\end{array}$ & $\begin{array}{l}0.015^{\star \star} \\
(0.005)\end{array}$ \\
\hline Interacted with Non Agricultural Household at Baseline (1997) $=1$ & & $\begin{array}{l}-0.002 \\
(0.002)\end{array}$ & & & & $\begin{array}{l}-0.003 \\
(0.002)\end{array}$ \\
\hline Interacted with Bigger Farm at Baseline (1997) $=1$ & & $\begin{array}{c}0.002 \\
(0.001)\end{array}$ & & & & $\begin{array}{c}0.002 \\
(0.001)\end{array}$ \\
\hline Interacted with Head's Age & & & $\begin{array}{l}0.0004^{\star \star} \\
(0.0001)\end{array}$ & & & $\begin{array}{l}0.0004^{\star *} \\
(0.0001)\end{array}$ \\
\hline Interacted with Head's Age Squared & & & $\begin{array}{c}-5.35^{\star} 10-6^{\star \star} \\
(0.0001)\end{array}$ & & & $\begin{array}{c}-5.30 * 10-6 * \star \\
(0.0001)\end{array}$ \\
\hline Interacted with Head has Not Completed Primary $=1$ & & & & $\begin{array}{l}0.003^{\star \star} \\
(0.001)\end{array}$ & & $\begin{array}{l}0.003^{\star} \\
(0.001)\end{array}$ \\
\hline Interacted with Head has Completed Primary or More $=1$ & & & & $\begin{array}{c}0.001 \\
(0.001)\end{array}$ & & $\begin{array}{c}0.001 \\
(0.002)\end{array}$ \\
\hline Interacted with Min Distance to Urban Center (/100) & & & & & $\begin{array}{c}-0.009 * \star \\
(0.001)\end{array}$ & $\begin{array}{c}-0.009 * \star \\
(0.001)\end{array}$ \\
\hline Full Set of Controls & $\mathrm{Y}$ & $\mathrm{Y}$ & $\mathrm{Y}$ & $\mathrm{Y}$ & $\bar{Y}$ & $\mathrm{Y}$ \\
\hline Number of Observations & 39529 & 39529 & 39529 & 39529 & 39529 & 39529 \\
\hline Mean of Dependent Variable (All) & 186.598 & 186.598 & 186.598 & 186.598 & 186.598 & 186.598 \\
\hline Mean of Dependent Variable (Controls) & 176.070 & 176.070 & 176.070 & 176.070 & 176.070 & 176.070 \\
\hline
\end{tabular}


Table 11: Are there Price Effects? Testing for Macro Income and Price Effects

Sub-sample of Ineligibles (Non-Poor) Households in October 1998, May 1999 and November 1999 -Intent to Treat (ITT)

\begin{tabular}{|c|c|c|c|c|c|c|c|}
\hline \multirow[b]{3}{*}{ A. Raw Means -no controls } & \multicolumn{3}{|c|}{ Treatment Group } & \multicolumn{3}{|c|}{ Control Group } & \multirow[b]{2}{*}{ t-stat } \\
\hline & $\mathbf{N}$ & Mean & SD & $\mathbf{N}$ & Mean & SD & \\
\hline & & & & & & & \\
\hline \multicolumn{8}{|l|}{ Al. Agricultural Investments } \\
\hline Draft Animal Ownership & 9053 & 37.23 & 0.483 & 5805 & 35.47 & 0.478 & 0.654 \\
\hline Number of Equivalent Draft Animals $†$ & 3341 & 0.90 & 1.523 & 2047 & 0.87 & 1.252 & 0.320 \\
\hline Production Animal Ownership & 9054 & 75.99 & 0.427 & 5805 & 75.23 & 0.432 & 0.447 \\
\hline Number of Production Animals $†$ & 6858 & 1.98 & 3.334 & 4345 & 1.98 & 3.389 & 0.005 \\
\hline Land Ownership & 9054 & 65.66 & 0.475 & 5806 & 64.74 & 0.478 & 0.423 \\
\hline Hectars of Land Used $†$ & 5819 & 2.98 & 3.000 & 3703 & 3.19 & 3.005 & -0.975 \\
\hline \multicolumn{8}{|l|}{ All. Micro-Enterprise Investments } \\
\hline Micro-Enterprise & 9054 & 9.21 & 0.289 & 5806 & 8.01 & 0.271 & 1.068 \\
\hline Female Micro-Enterprise & 9054 & 8.92 & 0.285 & 5806 & 7.34 & 0.261 & 1.477 \\
\hline \multicolumn{8}{|l|}{ Alll. Consumption ${ }^{1}$} \\
\hline Monthly Consumption per Capita (Home Production Included) $\dagger$ & 6155 & 261.74 & 197.939 & 3874 & 255.97 & 198.147 & 0.729 \\
\hline \multicolumn{8}{|l|}{ AIV. Community Wages } \\
\hline Monthly Male Agricultural Wage $\dagger$ & 860 & 605.13 & 202.668 & 488 & 613.94 & 195.336 & -0.520 \\
\hline Monthly Female Agricultural Wage $†$ & 364 & 534.53 & 191.883 & 197 & 516.00 & 188.584 & 0.884 \\
\hline Monthly Children Agricultural Wage $†$ & 318 & 437.42 & 183.389 & 160 & 421.03 & 162.437 & 0.811 \\
\hline
\end{tabular}


Table 12: Effect of OPORTUNIDADES on Private Transfers (Panels Al, All), Other Public Transfers (Panels BI, BII) and Activitities of Daily Living (Panel Cl) Sub-sample of Original Poor Households -Actual Treatments (TOT)

\begin{tabular}{|c|c|c|c|c|c|c|c|c|c|}
\hline & $\begin{array}{l}\text { Treatment } \\
\text { Status }\end{array}$ & $\begin{array}{c}\text { Potential } \\
\text { Transfer } \\
\text { (monthly) }\end{array}$ & $\begin{array}{l}\text { Potential } \\
\text { Transfer } \\
\text { Squared } \\
\text { (monthly) }\end{array}$ & $\begin{array}{c}\text { Cumulative } \\
\text { Transfer } \\
(6 \text { month } \\
\text { lag) }\end{array}$ & $\begin{array}{c}\text { Actual } \\
\text { Transfer } \\
\text { (monthly) }\end{array}$ & $\begin{array}{l}\text { Actual } \\
\text { Transfer } \\
\text { Squared } \\
\text { (monthly) }\end{array}$ & $\begin{array}{c}\text { Actual } \\
\text { Cumulative } \\
\text { Transfer } \\
\text { (6 month lag) }\end{array}$ & $\begin{array}{l}\text { Number } \\
\text { of Obs. }\end{array}$ & $\begin{array}{c}\text { Mean } \\
\text { Dep. Var. }\end{array}$ \\
\hline \multicolumn{10}{|l|}{ Al. Private Transfers ${ }^{1}=1$} \\
\hline Model AI.1 -PROBIT (Oct 98, Nov 99) & $\begin{array}{l}-0.002 \\
(0.005)\end{array}$ & & & & & & & 20847 & 0.070 \\
\hline Model Al.2 -PROBIT (Oct 98, Nov 99, Nov 00) & & $\begin{array}{l}-0.019 \\
(0.014)\end{array}$ & & & & & & 31071 & 0.067 \\
\hline Model Al.3 -PROBIT (Oct 98, Nov 99, Nov 00) & & $\begin{array}{l}-0.087^{\star} \\
(0.034)\end{array}$ & $\begin{array}{l}0.148^{*} \\
(0.059)\end{array}$ & & & & & 31071 & 0.067 \\
\hline Model Al.4 -2SLS (Oct 98, Nov 99, Nov 00) & & & & & $\begin{array}{l}-0.223^{\star *} \\
(0.067)\end{array}$ & $\begin{array}{l}0.531^{\star \star} \\
(0.193)\end{array}$ & & 31083 & 0.067 \\
\hline \multicolumn{10}{|l|}{ All. Private Transfers Amount (monthly) $\dagger$} \\
\hline Model All.1 -LS (Oct 98, Nov 99) & $\begin{array}{l}-54.798+ \\
(29.780)\end{array}$ & & & & & & & & \\
\hline Model All.2 -LS (Oct 98, Nov 99, Nov 00) & & $\begin{array}{l}-0.089 \\
(0.096)\end{array}$ & & & & & & 1512 & 337.618 \\
\hline Model All.3 -LS (Oct 98, Nov 99, Nov 00) & & $\begin{array}{l}-0.587^{*} \\
(0.234)\end{array}$ & $\begin{array}{c}0.001^{*} \\
(0.0004)\end{array}$ & & & & & 1512 & 337.618 \\
\hline Model All.4 -2SLS (Oct 98, Nov 99, Nov 00) & & & & & $\begin{array}{l}-1.235^{\star} \\
(0.498) \\
\end{array}$ & $\begin{array}{l}0.003^{*} \\
(0.001) \\
\end{array}$ & & 1512 & 337.618 \\
\hline \multicolumn{10}{|l|}{ BI. PublicTransfers ${ }^{2}=1$} \\
\hline Model BI.1 -PROBIT (Oct 98 - Nov 99) & $\begin{array}{l}-0.115^{\star \star} \\
(0.022)\end{array}$ & & & & & & & 30659 & 0.369 \\
\hline Model BI.2 -PROBIT (Oct 98 - Nov 00) & & $\begin{array}{l}-0.243^{\star \star} \\
(0.047)\end{array}$ & & & & & & 50208 & 0.346 \\
\hline Model BI.3 -PROBIT (Oct 98 - Nov 00) & & $\begin{array}{l}-0.537^{\star \star} \\
(0.126)\end{array}$ & $\begin{array}{l}0.611^{\star \star} \\
(0.190)\end{array}$ & & & & & 50208 & 0.346 \\
\hline Model BI.4 -2SLS (Oct 98 - Nov 00) & & & & & $\begin{array}{l}-0.611^{\star *} \\
(0.084)\end{array}$ & $\begin{array}{l}0.820^{\star *} \\
(0.202)\end{array}$ & & 50208 & 0.346 \\
\hline \multicolumn{10}{|l|}{ Bll. Public Transfers Amount (monthly) $\dagger$} \\
\hline Model BII.1 -LS (Oct 98 - Nov 99) & $\begin{array}{c}-9.534^{\star \star} \\
(3.472)\end{array}$ & & & & & & & 8732 & 90.544 \\
\hline Model BII.2 -LS (Oct 98 - Nov 00) & & $\begin{array}{l}-0.002 \\
(0.006)\end{array}$ & & & & & & 13881 & 91.991 \\
\hline Model BII.3 -LS (Oct 98 - Nov 00) & & $\begin{array}{l}-0.036^{*} \\
(0.017)\end{array}$ & $\begin{array}{l}6.55^{\star} 10-5^{\star} \\
\left(2.99^{\star} 10-5\right)\end{array}$ & & & & & 13881 & 91.991 \\
\hline Model BII.4 -2SLS (Oct 98 - Nov 00) & & & & & $\begin{array}{l}-0.073^{\star} \\
(0.032)\end{array}$ & $\begin{array}{l}1.69 * 10-4^{\star} \\
(7.74 * 10-5)\end{array}$ & & 13881 & 91.991 \\
\hline \multicolumn{10}{|l|}{ Cl. Activity of Dalily Living ${ }^{3}$ (ADL) } \\
\hline Model Cl.1 -LS (May 99 - Nov 99) & $\begin{array}{l}0.003+ \\
(0.002)\end{array}$ & & & & & & & 40491 & 0.978 \\
\hline Model Cl.2 -LS (May 99, Nov 99, Nov 00) & & $\begin{array}{l}0.073^{\star *} \\
(0.019)\end{array}$ & & & & & & 59907 & 0.979 \\
\hline Model Cl.3 -LS (May 99, Nov 99, Nov 00) & & $\begin{array}{l}0.065^{\star \star} \\
(0.021)\end{array}$ & & $\begin{array}{c}0.001 \\
(0.001)\end{array}$ & & & & 59907 & 0.979 \\
\hline Model Cl.4 -2SLS (May 99, Nov 99, Nov 00) & & & & & $\begin{array}{l}0.107^{\star \star} \\
(0.038)\end{array}$ & & & 59907 & 0.979 \\
\hline Model Cl.4 -2SLS (May 99, Nov 99, Nov 00) & & & & & $\begin{array}{l}0.112^{\star} \\
(0.048) \\
\end{array}$ & & $\begin{array}{r}-0.0001 \\
(0.003) \\
\end{array}$ & 59907 & 0.979 \\
\hline \multicolumn{10}{|c|}{$\begin{array}{l}\text { Notes: + } \text { significant at } 10 \%,{ }^{*} \text { significant at } 5 \%,{ }^{* *} \text { significant at } 1 \% \text {. For the probit models, marginal effects and robust standard errors clustered at the community level reported. LS and } 2 \text { SLS } \\
\text { regressions include community level random effects. All regressions include the following controls: wave dummies, head's and spouse's age, age squared and education level dummies, } \\
\text { head's ethnicity (language), household size adult equivalent, dummies controlling for household demographics, baseline assets (home ownership, dirt floor and electricity), farm size at } \\
\text { baseline and community characteristics (community organizations, distance to urban center and wages). Outliers trimmed at the top and bottom 0.5\% of the OPORTUNDADES (public) and } \\
\text { the private transfers distributions. For other public transfers, outliers trimmed at the top } 5 \% \text { of the distribution. +Conditional on being positive. } \\
{ }^{1} \text { Private transfers include both transfers from neighbours, relatives and friends living in the community and transfers received from migrants (conditional on a household member having } \\
\text { migrated during the } 5 \text { years before the interview). Estimation limited to rounds: Oct } 1998, \text { Nov } 1999 \text { and Nov } 2000 \text { due to non-existent or non-comparable data. }\end{array}$} \\
\hline \multicolumn{10}{|c|}{$\begin{array}{l}{ }^{2} \text { Public transfers }=1 \text { if someone in the household receives help from Procrampo, Niños con Solidaridad and/or DIF food package. Public transfer amount includes the total household } \\
\text { monetary value of the transfers received from Procampo and Niños con Solidaridad. Estimation limited to rounds Oct } 1998 \text { to Nov } 00 .\end{array}$} \\
\hline
\end{tabular}


Table 13: Potential Biases in the Consumption Equation: Private Transfers, Public Transfers and Increased Productivity. Sub-sample of Original Poor Households in October 1998 through November 2003 -Actual Treatments (TOT)

\begin{tabular}{|c|c|c|c|}
\hline & $\begin{array}{c}\text { Consumption } \\
\text { (2SLS) }\end{array}$ & $\begin{array}{c}\text { Consumption } \\
\text { (2SLS) }\end{array}$ & $\begin{array}{c}\text { Consumption } \\
\text { (2SLS) }\end{array}$ \\
\hline \multicolumn{4}{|l|}{ A. Private Transfers ${ }^{1}$-controls } \\
\hline Actual Transfer - monthly pc ae & $\begin{array}{l}1.055^{\star \star} \\
(0.049)\end{array}$ & & \\
\hline Total Actual Transfers (OPORTUNIDADES + Private) -monthly pc ae & & $\begin{array}{l}1.035^{\star \star} \\
(0.048)\end{array}$ & \\
\hline Total Actual Transfers (OPORTUNIDADES + Other Public + Private) -monthly pc ae & & & $\begin{array}{l}1.013^{\star \star} \\
(0.050)\end{array}$ \\
\hline Actual Cumulative Transfer -6 months lag pc ae & $\begin{array}{l}0.016^{\star \star} \\
(0.002)\end{array}$ & $\begin{array}{l}0.015^{\star \star} \\
(0.002) \\
\end{array}$ & $\begin{array}{l}0.010^{\star *} \\
(0.002) \\
\end{array}$ \\
\hline Number of Observations & 20282 & 20282 & 20267 \\
\hline Mean Consumption & 181.476 & 181.476 & 181.985 \\
\hline \multicolumn{4}{|l|}{ B. Public Transfers ${ }^{2}$-controls } \\
\hline Actual Transfer - monthly pc ae & $\begin{array}{l}0.913^{\star *} \\
(0.035)\end{array}$ & & \\
\hline Total Actual Transfers (OPORTUNIDADES + Other Public) -monthly pc ae & & $\begin{array}{l}0.961^{\star *} \\
(0.038)\end{array}$ & $\begin{array}{l}0.966^{\star \star} \\
(0.038)\end{array}$ \\
\hline Actual Cumulative Transfer -6 months lag pc ae & $\begin{array}{l}0.020^{\star \star} \\
(0.002)\end{array}$ & $\begin{array}{l}0.018^{\star *} \\
(0.002)\end{array}$ & $\begin{array}{l}0.018^{\star *} \\
(0.002)\end{array}$ \\
\hline Receive Food Package DIF =1 & & & $\begin{array}{l}7.454^{\star \star} \\
(2.302) \\
\end{array}$ \\
\hline $\begin{array}{l}\text { Number of Observations } \\
\text { Mean Consumption }\end{array}$ & $\begin{array}{c}30126 \\
181.916\end{array}$ & $\begin{array}{c}30126 \\
181.916\end{array}$ & $\begin{array}{c}30126 \\
181.916\end{array}$ \\
\hline \multicolumn{4}{|l|}{ C. Increased Productivity: Activity Daily Living $(A D L)^{3}$-controls } \\
\hline Actual Transfer - monthly pc ae & $\begin{array}{l}0.685^{\star \star} \\
(0.046)\end{array}$ & $\begin{array}{l}0.685^{\star \star} \\
(0.046)\end{array}$ & - \\
\hline Actual Cumulative Transfer -6 months lag pc ae & $\begin{array}{l}0.015^{\star \star} \\
(0.003)\end{array}$ & $\begin{array}{l}0.015^{\star \star} \\
(0.003)\end{array}$ & - \\
\hline Activity of Daily Living (ADL) Household's Head & & $\begin{array}{l}-1.500 \\
(7.706) \\
\end{array}$ & - \\
\hline Number of Observations & 13179 & 13179 & - \\
\hline Mean Consumption & 175.236 & 175.236 & - \\
\hline \multicolumn{4}{|c|}{$\begin{array}{l}\text { Notes: +significant at } 10 \%,{ }^{*} \text { significant at } 5 \%,{ }^{* *} \text { significant at } 1 \% \text {. SE in parentheses. All regressions include random effects at the community level and the following } \\
\text { controls: wave dummies, head's and spouse's age, age squared and education level dummies, head's ethnicity (language), household size adult equivalent and household } \\
\text { demographic variables, baseline assets (home ownership, dirt floor and electricity), farm size at baseline and community characteristics (community organizations, distance } \\
\text { to urban center and wages). Consumption is expenditures expressed in per capita adult equivalent units and includes home production. Outliers trimmed at the top and } \\
\text { bottom } 1 \% \text { of the consumption and the total transfer distributions. pc means "per capita"; ae means "adult equivalent". }\end{array}$} \\
\hline \multicolumn{4}{|c|}{$\begin{array}{l}{ }^{1} \text { Because of the inclusion of home production and private transfers, estimation is limited to the following rounds: October } 1998 \text { and November } 2000 . \text { Private transfers include } \\
\text { both transfers from neighbours, relatives and friends living in the community and transfers received from migrants (conditional on a household member having migrated } \\
\text { during the } 5 \text { years before the interview). }\end{array}$} \\
\hline $\begin{array}{l}{ }^{2} \text { Because of the inclusion of home production, estimation is limited to the rounds of October } 199 \\
\text { household monetary value of the transfers received from Procampo and Niños con Solidaridad. } \\
\text { during the past month. }\end{array}$ & $\begin{array}{l}1999 \text { and Novembe } \\
\text { if someone in the } r\end{array}$ & $\begin{array}{l}\text { 00. Public transfer } \\
\text { ehod has received }\end{array}$ & $\begin{array}{l}\text { Ide the total } \\
\text { sidized food package }\end{array}$ \\
\hline
\end{tabular}


Table 14: Investment or Precautionary Savings?

Sub-sample of Original Poor Households in November 2003 -Actual Treatments (TOT)

\begin{tabular}{|c|c|c|c|c|c|c|}
\hline & $\begin{array}{c}\text { Draft } \\
\text { Animal } \\
\text { Ownership } \\
\text { (2SLS) }\end{array}$ & $\begin{array}{c}\text { Number of } \\
\text { Equivalent } \\
\text { Draft } \\
\text { Animals } \\
\text { p(yly >0) } \\
\text { (2SLS) }\end{array}$ & $\begin{array}{l}\text { Production } \\
\text { Animal } \\
\text { Ownership } \\
\text { (2SLS) }\end{array}$ & $\begin{array}{c}\text { Number of } \\
\text { Equivalent } \\
\text { Production } \\
\text { Animals } \\
\text { p(yly }>0) \\
(2 S L S)\end{array}$ & $\begin{array}{l}\text { Land Use } \\
\text { (2SLS) }\end{array}$ & $\begin{array}{c}\text { Number of } \\
\text { Hectares } \\
\text { Used } \\
\text { p(yly >0) } \\
\text { (2SLS) }\end{array}$ \\
\hline \multicolumn{7}{|l|}{ Model A: TOT -controls } \\
\hline \multirow[t]{2}{*}{ High Risk Area } & 0.020 & 0.086 & $0.117^{\star \star}$ & 0.097 & $0.147^{\star \star}$ & -1.545 \\
\hline & $(0.049)$ & $(0.300)$ & $(0.036)$ & $(0.221)$ & $(0.048)$ & $(0.970)$ \\
\hline \multirow[t]{2}{*}{ Total Household Actual Cumulative Transfer (/1000) } & $0.004^{*}$ & -0.004 & $0.004^{*}$ & 0.002 & 0.002 & -0.008 \\
\hline & $(0.002)$ & $(0.013)$ & $(0.002)$ & $(0.008)$ & $(0.002)$ & $(0.027)$ \\
\hline \multirow[t]{2}{*}{ High Risk Area * Total HH Actual Cumulative Transfer (/1000) } & 0.000 & -0.020 & $-0.006^{\star *}$ & 0.001 & $-0.008^{\star *}$ & 0.081 \\
\hline & $(0.003)$ & $(0.016)$ & $(0.002)$ & $(0.014)$ & $(0.003)$ & $(0.056)$ \\
\hline \multicolumn{7}{|l|}{ Model B: TOT -controls } \\
\hline \multirow[t]{2}{*}{ High Risk Area } & 0.009 & $-0.806+$ & 0.094 & -0.288 & 0.037 & -0.509 \\
\hline & $(0.101)$ & $(0.421)$ & $(0.078)$ & $(0.398)$ & $(0.098)$ & $(1.870)$ \\
\hline \multirow[t]{2}{*}{ Total Household Actual Cumulative Transfer (/1000) } & -0.001 & -0.073 & 0.003 & $-0.057^{*}$ & 0.006 & $-0.197+$ \\
\hline & $(0.006)$ & $(0.046)$ & $(0.005)$ & $(0.028)$ & $(0.006)$ & $(0.113)$ \\
\hline \multirow[t]{2}{*}{ Total Household Actual Cumulative Transfer Squared (/1000) } & 0.000 & 0.002 & 0.000 & $0.002^{\star}$ & 0.012 & $0.006+$ \\
\hline & $(0.000)$ & $(0.001)$ & $(0.000)$ & $(0.001)$ & $(0.015)$ & $(0.003)$ \\
\hline \multirow[t]{2}{*}{ High Risk Area * Total HH Actual Cumulative Transfer (/1000) } & 0.002 & $0.132+$ & -0.002 & 0.068 & -0.000 & -0.099 \\
\hline & $(0.018)$ & $(0.071)$ & $(0.012)$ & $(0.072)$ & $(0.000)$ & $(0.324)$ \\
\hline \multirow[t]{2}{*}{ High Risk Area * Total HH Actual Cumulative Transfer Squared (/1000) } & -0.000 & $-0.005^{\star}$ & -0.000 & -0.002 & -0.001 & 0.006 \\
\hline & $(0.001)$ & $(0.002)$ & $(0.000)$ & $(0.002)$ & $(0.000)$ & $(0.012)$ \\
\hline Observations TOT Sub-Sample & 9953 & 2968 & 9957 & 7366 & 10009 & 6342 \\
\hline Mean Dependent Variable ТОТ Sub-Sample & 0.303 & 1.147 & 0.746 & 1.066 & 0.681 & 3.694 \\
\hline Proportion Households in High Risk Areas & 0.093 & 0.104 & 0.093 & 0.097 & 0.093 & 0.094 \\
\hline
\end{tabular}




\section{APPENDIX 2 -GRAPHS}

Graph 1: OPORTUNIDADES Program Take up Rates Over Time

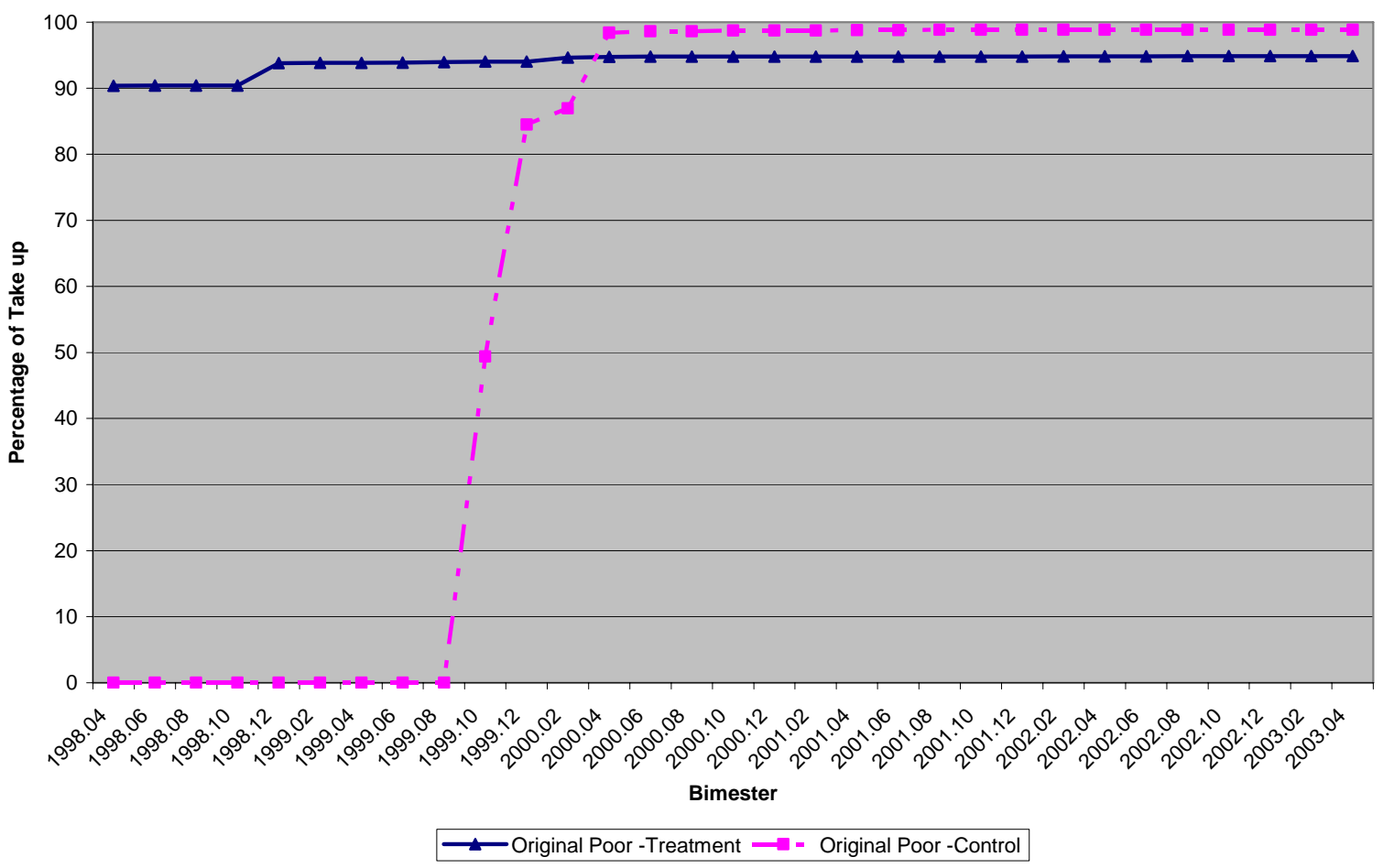

Graph 2: Share of Households by Number of Children Enrolled from 3rd Grade of Primary to 3rd Grade of Junior High School at Baseline (October 1997).

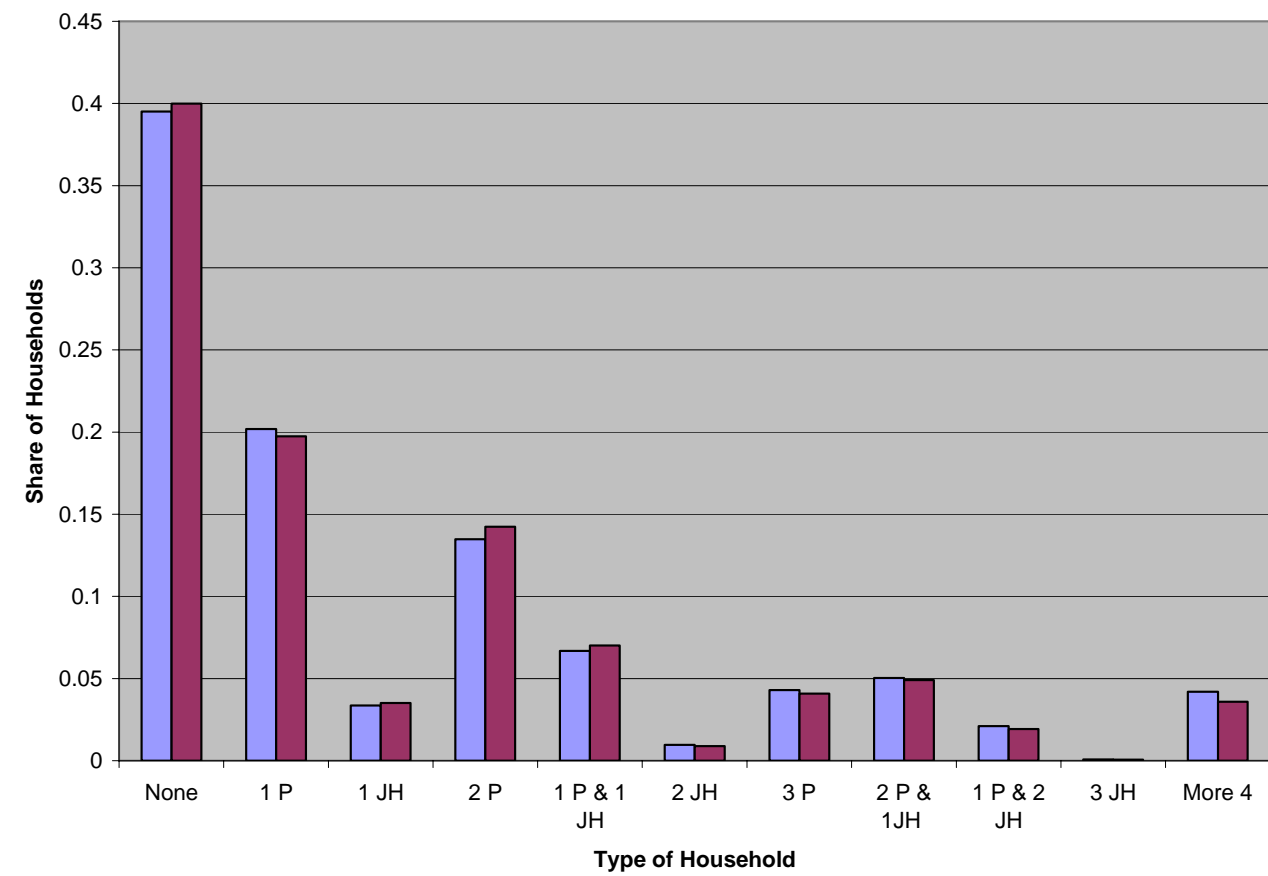

Note: $\mathrm{P}=$ Primary School; JH =Junior High School 

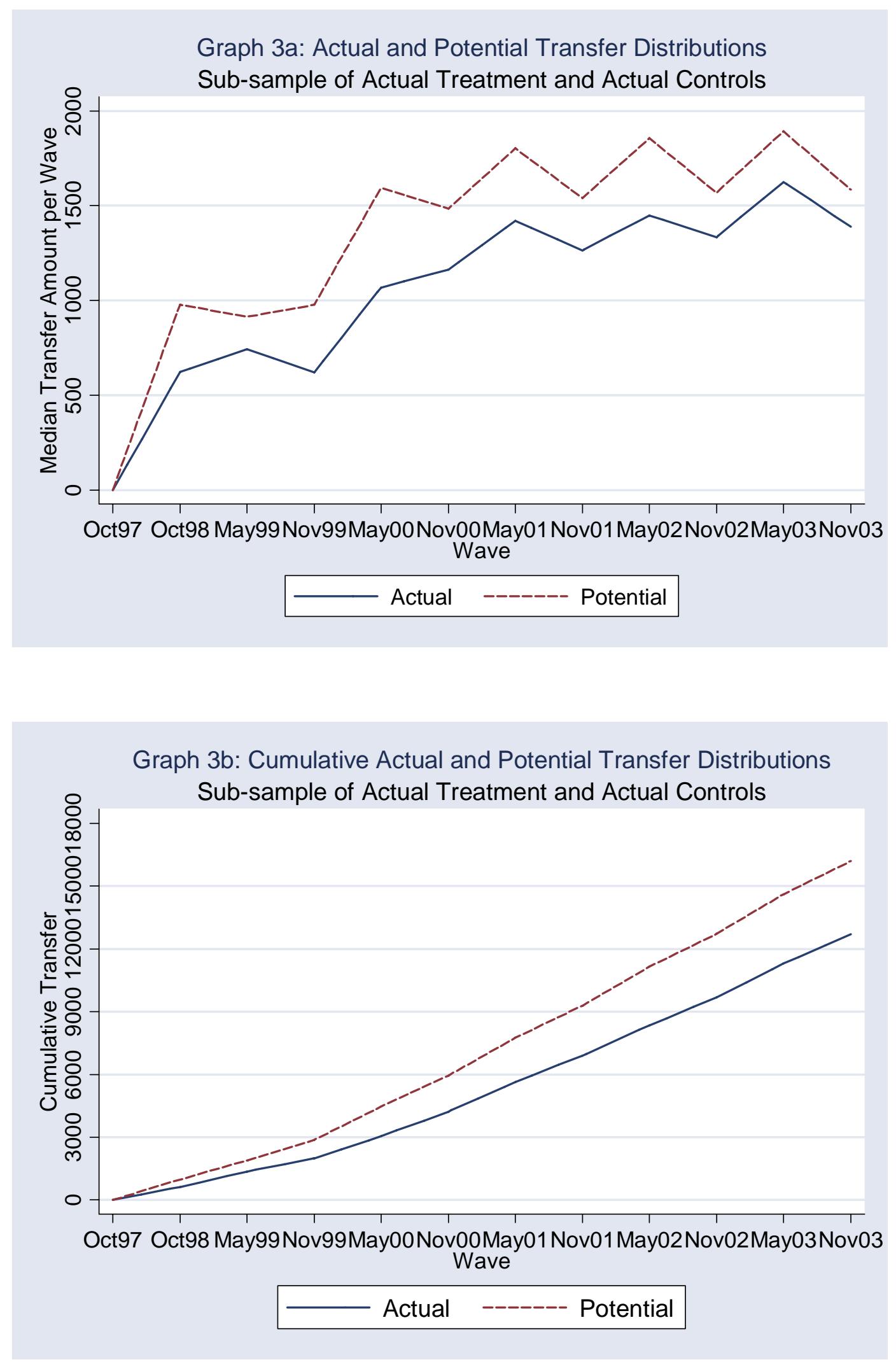
Graph 4: Mean Actual and Potential Cumulative Transfer Amount by Quintile

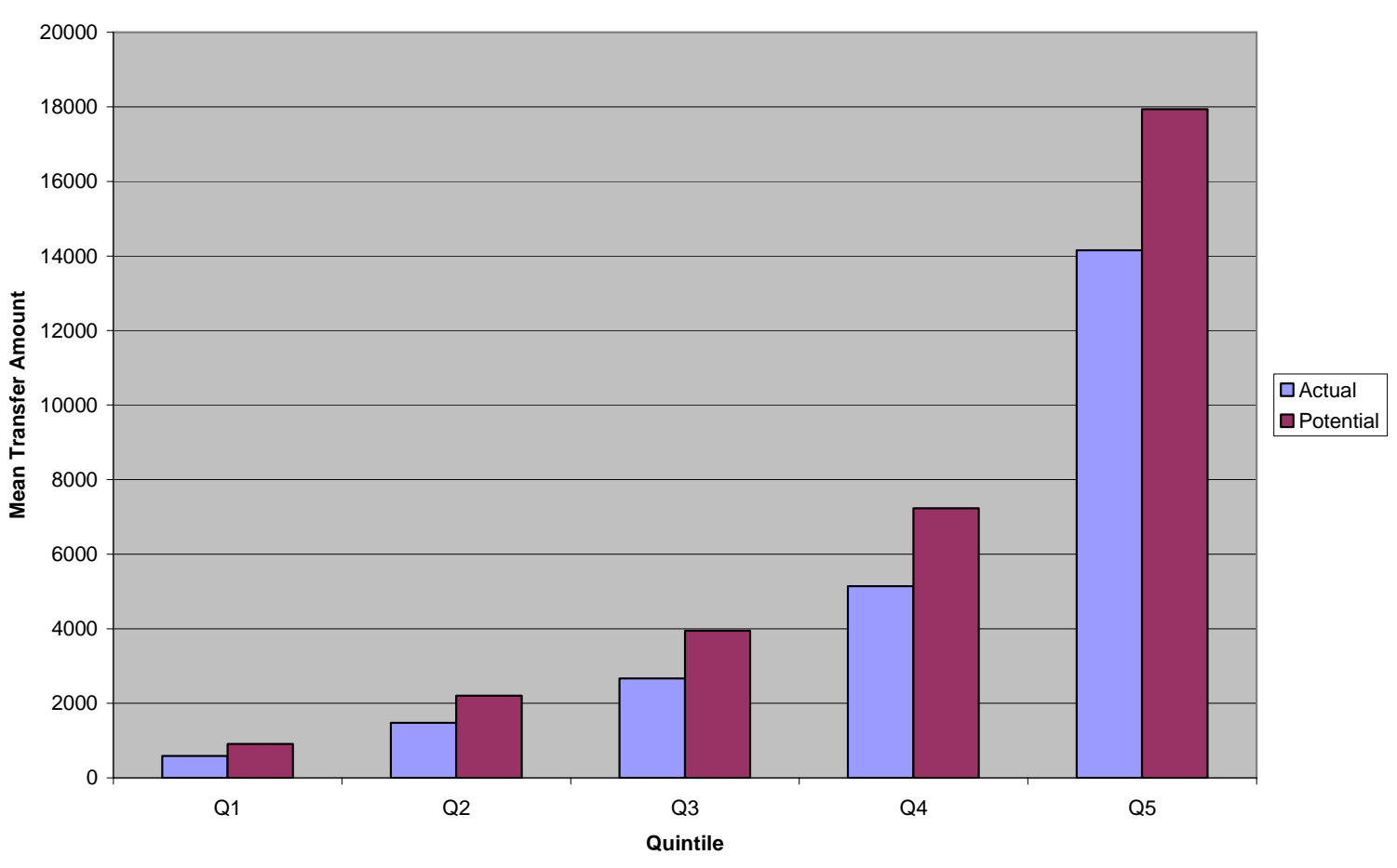

